\title{
Autism genetics: searching for specificity and convergence
}

Jamee M Berg ${ }^{1,2,3}$ and Daniel H Geschwind ${ }^{2,3,4 *}$

\begin{abstract}
Advances in genetics and genomics have improved our understanding of autism spectrum disorders. As many genes have been implicated, we look to points of convergence among these genes across biological systems to better understand and treat these disorders.
\end{abstract}

Autism spectrum disorders (ASDs) are a group of neuropsychiatric disorders that include autism, pervasive developmental disorder not otherwise specified (PDDNOS), and Asperger's syndrome [1]. First described in 1943, their diagnostic features continue to evolve based on an expanding clinical and biological understanding [2]. A child is diagnosed with an ASD if he or she shows early childhood deficits in: social communication and interaction, involving social reciprocity, non-verbal communication, and maintenance of relationships; language development, such as delay of language onset and maintenance of conversation; and restrictive and repetitive behaviors, including in speech, motor movements, routines, and interests [3]. Classic autism, formally known as autistic disorder, is the most severe of the ASDs, with patients showing impairments in social, communication, and restrictive and repetitive behavior before the age of three. Additional features that are often comorbid with ASDs include sensory and motor abnormalities, attention deficit hyperactivity disorder (ADHD), epilepsy, and developmental regression $[4,5]$. Those with ASDs can range from being mentally disabled to having above average intelligence [6]. ASDs are extremely prevalent in our society, with males being affected more than females, especially in high-functioning cases including what is currently known as Asperger's syndrome. Currently, it is estimated that one out of 88

\footnotetext{
*Correspondence: dhg@ucla.edu

2Semel Institute for Neuroscience and Human Behavior, University of California, Los Angeles, CA 90095, USA

Full list of author information is available at the end of the article
}

children has an ASD, representing a 78\% increase over the past 6 years [7]. This drastic increase is most likely due to sociocultural factors rather than biological factors, including age at diagnosis, changing diagnostic criteria, and broader inclusion rates, although genetic and environmental factors cannot be ruled out [8-11].

ASDs have a large genetic component. Concordance rates among monozygotic twins, dizygotic twins, and siblings are $50-90 \%, 0-30 \%$, and $3-26 \%$, respectively, supporting a major genetic contribution [12-14]. Interestingly, the risk of ASD in second-born male siblings is threefold that in second-born females, supporting models of reduced penetrance in females [14,15]. Moreover, a recent study found a roughly twofold greater ASD concordance among full siblings than in half siblings, additionally supporting a genetic contribution and heritability of greater than 50\% [16]. Multiple converging research strategies to account for ASD genetic liability have identified a variety of genetic causes that account for roughly $20 \%$ of ASD cases. These include genetic copy number variation (CNV; duplicated or deleted regions of the genome greater than $1 \mathrm{~kb}$ [17]), syndromic forms of autism (ASD that occurs within a defined syndrome, such as fragile $\mathrm{X}$ syndrome), and single gene and metabolic disorders $[18,19]$. Recent studies based on CNV and single nucleotide variant (SNV) data put the number of ASD-implicated genes at between 200 and 1,000 [20-25], and multiple modes of inheritance have been proposed [26-28]. In addition, many ASD-implicated genes are also associated with other neuropsychiatric disorders, including schizophrenia, ADHD, epilepsy, and intellectual disability [22,29-40], and none are specific for autism, suggesting that additional modifying factors dictate the clinical outcome of having disruptions in a specific gene.

The genetic complexity of ASDs mirrors their phenotypic complexity. The core domains within ASD phenotypes - social, language and restrictive and repetitive also exist as a spectrum, with a distribution overlapping with extreme forms of normal behavior [41]. These subclasses of impairments, or 'endophenotypes', are also observed at some degree in unaffected family members, but are below threshold for clinical diagnosis [42]. 
Here, we first provide an overview of our most recent understanding of the genetics of ASDs and then highlight convergent pathways and biological mechanisms emerging from gene finding and expression studies. The areas in which molecular mechanisms intersect have great potential to guide future genetic discoveries and to aid in therapeutic design.

\section{The current state of autism genetics}

ASD-associated variants have been identified over the past three decades using various techniques; recently, next-generation sequencing on large cohorts has ushered in a wave of gene discovery that has greatly enhanced our understanding of the inheritance of ASDs. Previous work involved the cataloging of ASD-associated major gene disorders, such as fragile $\mathrm{X}$ syndrome and tuberous sclerosis $[43,44]$, cytogenetic analysis, which identified large structural genomic rearrangements, and genetic linkage studies [45]. Over the past several years, genomewide association studies (GWAS) have revealed a handful of common alleles of modest effect size likely to contribute to ASD [46-48]. Analysis of CNV has additionally implicated rare genomic structural changes, both de novo and inherited, of large effect size [20,21,49-52]. Most recently, exome sequencing has lent insight into the contribution of de novo SNVs [22-25]. In this section we review the major studies that have identified both common variants (CVs) and rare variants (RVs) associated with ASDs and will discuss models for how these variants may contribute to ASD pathology.

\section{The contribution of common alleles versus rare alleles}

The contribution of both common and rare alleles to ASD has been assessed using GWAS and CNV/exome sequencing studies. Given that ASD is highly prevalent, it was initially thought (consistent with the prevailing common variant-common disease model [53]) that common genetic single nucleotide polymorphism (SNP) variants (those occurring in at least 5\% [54] of the population) would lead to this common disorder.

An alternative model is that RVs with moderate to large effect size lead to ASD (the rare variant-common disease model [55]). This is supported by mathematical modeling based on recurrence in multiplex families, which posits a relatively large contribution from spontaneous, de novo mutations with lower penetrance in females [15]. The contribution of RVs has been tested by measuring the frequency of rare CNVs and SNVs in cases and controls and is emerging as an exciting area in ASD genetics. Both types of study have been aided by the availability of large cohorts of ASD and control participants, specifically the Autism Genetic Resource Exchange (AGRE), Simons Simplex Collection (SSC), Autism Center of Excellence (ACE), and the Autism Genome Project AGP). Findings from these studies, outlined in Tables 1-3, are discussed below.

Three large-scale GWAS have been conducted so far [46-48] that are adequately powered to detect CVs of modest effect size (Table 3). Only two variants reached genome-wide significance: an intergenic variant, rs4307059, between cadherin $9(\mathrm{CDH} 9)$ and cadherin 10 $(C D H 10)$ [46] and rs4141463 in an intronic region of the MACRO domain containing 2 (MACROD2) gene [48]. An additional intergenic variant, rs10513025, between SEMA5A and TAS2R1, had a $p$-value suggestive of genome-wide significance $\left(\mathrm{p}=2.1 \times 10^{-7}\right)$ [47].

What conclusions can be made from GWAS? First, the effect size for any single CV is rather small, as studies have had the power to detect odds ratios (ORs) of greater than 1.5 but have not found such variants. This suggests either widespread epistasis, or that multiple CVs of small effect size are needed for disease, or, alternatively, that the role for CVs in limited (Figure 1). Second, using unaffected relatives as controls, who under some models may harbor a sub-threshold genetic load of associated variants, would decrease the association signal. Studies of endophenotypes or intermediate phenotypes are one strategy that may help in this regard [29]. Third, the epistatic interaction of combinations of CVs, rather than single variants, may confer disease risk, prompting the need for bioinformatic tools capable of testing combinatorial models. In sum, GWAS has not provided evidence that single $\mathrm{CVs}$ ranging from modest to large effect contribute significantly to ASD risk. However, at the same time, the cohorts tested have been relatively small compared with the tens of thousands of patients tested in other common diseases [56,57].

This has led many to a model in which RVs (either CNVs or rare SNVs) of moderate to large effect explain a large proportion of ASD heritability [15]. Over the past 5 years, 6 major studies have conducted refined screens of the genome to identify rare CNVs, both inherited and de novo, in ASD participants and matched controls (Table 2). These studies have shed light on the contribution of rare CNVs to ASD pathophysiology, with several themes emerging. First, in all five studies that examined inherited CNVs, inherited CNVs were equally prevalent in individuals with ASD as in controls [20,21,50,51]. Although one study reports a 1.19-fold higher number of CNVs (de novo and inherited) in cases than in controls, this signal is driven by the contribution of rare de novo CNVs, as removing these CNVs from the analysis results in an equal distribution of CNVs between cases and controls [52]. Second, the emerging consensus from multiple studies is that larger CNVs, containing more genes, are observed in probands versus controls [20,21, 50,51]. Third, these studies do not consistently find that simplex families (those with only one member with an 
Table 1. Whole-exome gene finding sequencing studies that reveal common and rare variants associated with ASD

\begin{tabular}{|c|c|c|c|c|c|}
\hline References & Participants & $\begin{array}{l}\text { De novo variant } \\
\text { characteristics }\end{array}$ & $\begin{array}{l}\text { Single genes } \\
\text { implicated }\end{array}$ & Novel findings & Trends \\
\hline $\begin{array}{l}\text { Neale et al. } \\
2012 \text { [24] }\end{array}$ & $\begin{array}{l}175 \text { families*, simplex/ } \\
\text { multiplex and trios. } \\
175 \text { cases, } 350 \text { parents }\end{array}$ & $\begin{array}{l}\text { Equal frequency of } \\
\text { de novo mutations in } \\
\text { cases and control }\end{array}$ & $\begin{array}{l}\text { KATNAL2 and CHD8 harbor } \\
\text { de novo mutations in cases, } \\
\text { none found in controls } \\
\text { ( } 935 \text { cases versus } 870 \\
\text { controls; targeted exome } \\
\text { sequencing) }\end{array}$ & $\begin{array}{l}\text { Significantly enriched number } \\
\text { of protein interactions among } \\
\text { genes with missense or } \\
\text { nonsense de novo mutations }\end{array}$ & $\begin{array}{l}\text { Greater paternal and } \\
\text { maternal age correlates } \\
\text { with greater number of } \\
\text { de novo mutations }\end{array}$ \\
\hline $\begin{array}{l}\text { O'Roak et al. } 2012 \\
\text { [22] }\end{array}$ & $\begin{array}{l}209 \text { families (SSC), } \\
\text { simplex, trios and } \\
\text { quads. } 209 \text { cases, } 418 \\
\text { parents, } 50 \text { unaffected } \\
\text { sibs }\end{array}$ & $\begin{array}{l}\text { Equal frequency of } \\
\text { de novo mutation in } \\
\text { cases and controls }\end{array}$ & $\begin{array}{l}\text { ASD cases harbor protein- } \\
\text { disrupting mutations in } \\
\text { GRIN2B, LAMC3, and SCN1A } \\
\text { (mutation sCreening; } 1,703 \\
\text { ASD cases, } 744 \text { controls) } \\
\text { and CHD8 and NTNG1 } \\
\text { (recurrent) }\end{array}$ & $\begin{array}{l}\text { Genes with de novo mutations } \\
\text { that cause missense or nonsense } \\
\text { mutations form a } \beta \text {-catenin/ } \\
\text { chromatin remodeling protein } \\
\text { network enriched for ASD } \\
\text { candidate genes }\end{array}$ & $\begin{array}{l}\text { 4:1 paternal origin of de } \\
\text { novo mutations. Greater } \\
\text { paternal age correlates } \\
\text { with greater number of } \\
\text { de novo SNVs }\end{array}$ \\
\hline $\begin{array}{l}\text { Sanders et al. } \\
2012 \text { [25] }\end{array}$ & $\begin{array}{l}238 \text { families (SSC), } \\
\text { simplex, trios and } \\
\text { quads. } 238 \text { cases, } \\
476 \text { parents, } 200 \\
\text { unaffected sibs }\end{array}$ & $\begin{array}{l}\text { Equal frequency of } \\
\text { de novo mutation in } \\
\text { cases and controls }\end{array}$ & $\begin{array}{l}\text { SCN2A significantly } \\
\text { associated with ASD. } \\
\text { KATNAL2, CHD8, and SCN2A } \\
\text { significantly associated with } \\
\text { ASD when combined with } \\
{[22,24]}\end{array}$ & $\begin{array}{l}\text { Significantly greater non- } \\
\text { synonymous and nonsense } \\
\text { de novo SNVs in cases than } \\
\text { unaffected sibs (all genes and } \\
\text { brain-expressed genes), OR } 1.93 \\
\text { for non-synonymous to silent } \\
\text { SNVs in cases versus unaffected } \\
\text { sibs }\end{array}$ & $\begin{array}{l}\text { Greater paternal age } \\
\text { correlates with greater } \\
\text { number of de novo SNVs }\end{array}$ \\
\hline $\begin{array}{l}\text { lossifov et al. } \\
2012 \text { [23] }\end{array}$ & $\begin{array}{l}343 \text { families (SSC), } \\
\text { simplex, quads. } 343 \\
\text { cases, } 686 \text { parents, } 343 \\
\text { unaffected sibs }\end{array}$ & $\begin{array}{l}\text { Equal frequency of } \\
\text { de novo mutation in } \\
\text { cases and controls }\end{array}$ & $\begin{array}{l}\text { KATNAL2, CHD8, SCN2A, } \\
\text { DYRK1A, and POGZ } \\
\text { significantly associated with } \\
\text { ASD when combining all } \\
\text { studies [22-25] }\end{array}$ & $\begin{array}{l}\text { Twofold higher numbers of } \\
\text { frame-shift, splice-site, and } \\
\text { nonsense de novo mutations in } \\
\text { cases than in unaffected sibs. } \\
\text { Enriched number of gene- } \\
\text { disrupting mutations in FMRP- } \\
\text { associated genes ([23] alone and } \\
\text { when combining data from all } \\
\text { studies [22-25]) }\end{array}$ & $\begin{array}{l}\text { Greater paternal and } \\
\text { maternal age correlates } \\
\text { with greater number of } \\
\text { de novo mutations }\end{array}$ \\
\hline
\end{tabular}

* Boston Autism Consortium

ASD) harbor many more large de novo mutations than multiplex families (those with more than one). For example, whereas two studies report a higher number of de novo events in simplex than in multiplex families $(10 \%$ simplex versus 3\% multiplex [49] and 7\% simplex versus $2 \%$ multiplex [51]), another reports an even distribution of de novo events across the two types of families $(5.6 \%$ simplex versus $5.5 \%$ multiplex [52]). Lastly, many CNVs are multigenic, especially in the genomes of people with ASD, making it difficult to determine the putative causative gene. Determination of pathogenicity of specific genes or pathways may be aided by modeling in animals [58], intersection with other functional data such as gene expression [59], and systems biology approaches, as discussed below. In any case, these large-scale CNV studies have generated the following list of intriguing ASD candidate genes disrupted by rare de novo CNVs in ASD participants: A2BP1, ANKRD11, C16orf72, CDH13, CDH18, DDX53, DLGAP2 [51,52], DPP6, DPYD, FHIT, FLJ16237, NLGN4, NRXN1, SHANK2, SHANK3, SLC4A10, SYNGAP1, and USP7 [20,21] (Table 2).

Advances in next-generation sequencing now enable the most powerful approach to finding de novo RVs. Four independent groups have recently conducted wholeexome sequencing projects using non-overlapping samples [22-25] (Table 1). Strikingly, across all four studies, the frequency of de novo mutation was equal between ASD and control participants. Another commonality across studies was the correlation between older fathers and increased number of de novo point mutations, which could help explain the paternal-age-dependent risk for ASD [60-63]. In addition, two studies report an increase in gene-disrupting SNVs in ASD individuals versus unaffected siblings, although the overall SNV mutation rate is equal between probands and siblings [23,25]. In one study [25], there was a significantly greater number of non-synonymous and nonsense de novo SNVs in ASD individuals than in unaffected siblings when looking across all genes (OR of 1.93 (all non-synonymous to silent SNVs); OR of 4.03 (nonsense/splice-site to silent SNVs) and brain-expressed genes only (OR of 2.22 (all nonsynonymous to silent SNVs); OR of 5.65 (nonsense/ splice-site mutations to silent SNVs)), with silent SNVs showing an equal mutation rate between cases and controls. The other study [23] reported a twofold higher number of frame-shift, splice-site, and nonsense de novo 


\begin{tabular}{|c|c|c|c|c|c|}
\hline References & Participants & $\begin{array}{l}\text { All CNVs (de novo } \\
\text { and inherited) }\end{array}$ & De novo CNVs only & $\begin{array}{l}\text { Recurrent de novo or } \\
\text { inherited CNVs in cases }\end{array}$ & $\begin{array}{l}\text { Single genes, } \\
\text { ASD-associated } \\
\text { genes and regions in } \\
\text { de novo CNVs found } \\
\text { in cases }\end{array}$ \\
\hline $\begin{array}{l}\text { Sebat et al. } \\
2007 \text { [49] }\end{array}$ & $\begin{array}{l}264 \text { families (AGRE/NIMH), } \\
118 \text { simplex, } 47 \text { multiplex, } \\
99 \text { control, } 195 \text { cases, } 196 \\
\text { controls }\end{array}$ & Focused on CNVs only & $\begin{array}{l}7.2 \% \text { of cases; } 1 \% \text { of } \\
\text { controls; de novo variants } \\
\text { larger than } 3 \mathrm{Mb}: 2.6 \% \text { of } \\
\text { cases; } 0.51 \% \text { of controls }\end{array}$ & $\begin{array}{l}\text { De novo: } 2 \text { q37.3 ( } 2 \text { del), } \\
\text { 3p14.2 (1 dup, } 1 \text { del) (cases } \\
\text { only) }\end{array}$ & $\begin{array}{l}\text { SLC4A10, FHIT, } \\
\text { FLJ16237, A2BP1 }\end{array}$ \\
\hline $\begin{array}{l}\text { Szatmari et al. } \\
2007[50]\end{array}$ & $\begin{array}{l}173 \text { families (AGP), } \\
\text { multiplex, } 196 \text { cases, } 292 \\
\text { unaffected sibs }\end{array}$ & $\begin{array}{l}624 \text { total; no significant } \\
\text { difference in frequency of } \\
\text { CNVs overall in cases and } \\
\text { controls. } 1.3 \text { CNVs/genome } \\
\text { in cases; mean size, } 3.4 \\
\text { Mb; } 1.27 \text { CNVs/genome in } \\
\text { controls; mean size, } 4.3 \mathrm{Mb}\end{array}$ & $\begin{array}{l}5.1 \% \text { of cases, } 2.1 \% \text { of } \\
\text { controls }\end{array}$ & $\begin{array}{l}47 \text { CNVs (18 regions) in } \\
\text { cases }\end{array}$ & $\begin{array}{l}\text { 17p12, 22q11.2, } \\
\text { NRXN1 }\end{array}$ \\
\hline $\begin{array}{l}\text { Marshall et al. } \\
2008 \text { [51] }\end{array}$ & $\begin{array}{l}427 \text { families, } 237 \text { simplex, } \\
189 \text { multiplex, } 427 \text { cases, } \\
500 \text { controls (unrelated), } \\
1,152 \text { additional controls }\end{array}$ & $\begin{array}{l}\text { 2,873 total. No significant } \\
\text { difference in frequency of } \\
\text { CNVs overall in cases and } \\
\text { controls. } 3.1 \text { CNVs/genome } \\
\text { in cases; mean size, } 603 \\
\text { kb; } 3.1 \mathrm{CNVs} / \text { genome in } \\
\text { controls ( }=500) \text {; mean } \\
\text { size, } 470 \mathrm{~kb}\end{array}$ & $\begin{array}{l}27 \text { ASD cases with de novo } \\
\text { variants not found in } 1,152 \\
\text { additional controls }\end{array}$ & $\begin{array}{l}\text { 983/94 (overlapping CNV/ } \\
\text { loci) in } 427 \text { cases; } 31 / 13 \\
\text { case-only (overlapping } \\
\text { CNV/loci) not found in } \\
\text { 1,152 additional controls. } \\
\text { De novo: } 5 \text { p15.31-p15.2 ( } 2 \\
\text { del) 7q31.1-q32.2 ( } 2 \text { del) } \\
\text { 15q11.2-q13.3 (2 dup) } \\
\text { 16p11.2 (1 dup, } 2 \text { del) }\end{array}$ & $\begin{array}{l}\text { CDH18, DPYD, NLGN4, } \\
\text { DPP6, DLGAP2, } \\
\text { ANKRD11, SHANK3 }\end{array}$ \\
\hline $\begin{array}{l}\text { Pinto et al. } \\
2010 \text { [52] }\end{array}$ & $\begin{array}{l}876 \text { families (AGP), } \\
\text { simplex/multiplex, } 996 \\
\text { cases, 1,752 parents, 1,287 } \\
\text { additional controls }\end{array}$ & $\begin{array}{l}\text { 5,478 total. 1.19-fold } \\
\text { increase in CNVs in cases } \\
\text { over controls.1.69 case/ } \\
\text { control ratio for CNVs } \\
\geq 500 \mathrm{~kb} .219 \text { inherited } \\
\text { CNVs not in controls and } \\
\text { disrupting single genes } \\
\text { (DDX53-PTCHD1) }\end{array}$ & $\begin{array}{l}50 \text { out of } 876 \text { of ASD cases } \\
\text { harbor de novo CNVs. } \\
\text { Seven de novo CNVs not } \\
\text { in controls and disrupting } \\
\text { single genes }\end{array}$ & NA & $\begin{array}{l}\text { SHANK2, SYNGAP1, } \\
\text { DLGAP2 }\end{array}$ \\
\hline $\begin{array}{l}\text { Sanders et al. } \\
2011[21]\end{array}$ & $\begin{array}{l}\text { 1,124 families* (SSC), } \\
\text { simplex, 1,124 cases, 2,248 } \\
\text { parents, } 872 \text { unaffected } \\
\text { sibs }\end{array}$ & $\begin{array}{l}\text { No significant difference } \\
\text { in frequency of inherited } \\
\text { CNVs in cases and controls }\end{array}$ & $\begin{array}{l}\text { Cases }(n=872) \text {, controls } \\
\text { ( } n=872) \text {. All de novo CNVs: } \\
5.9 \% \text { of cases; } 1.7 \% \text { of } \\
\text { sibs OR: } 3.5 . \text { Multigenic de } \\
\text { novo CNVs: } 4.9 \% \text { of cases; } \\
0.92 \% \text { sibs; OR: } 5.6 \text {. Mean } \\
\text { number of genes/CNV } 21.4 \\
\text { in cases; } 4.6 \text { in sibs. De novo } \\
\text { variants larger than } 1 \mathrm{Mb} \text { : } \\
2.5 \% \text { cases; } 0.5 \% \text { controls, } \\
\text { OR: } 5.6\end{array}$ & $\begin{array}{l}\text { Denovo: 1q21.1 (2 } \\
\text { dup); } 7 \mathrm{q} 11.23 \text { (4 dup); } \\
\text { 15q13.2-q13.3 (1 dup/1 } \\
\text { del); } 16 \mathrm{p} 11.2 \text { (4 dup, } 7 \text { del); } \\
\text { 16p13.2 (2 dup); 16q23.3 } \\
\text { (2 del) }\end{array}$ & CDH13, USP7, C16orf72 \\
\hline $\begin{array}{l}\text { Levy et al. } \\
2011 \text { [20] }\end{array}$ & $\begin{array}{l}887 \text { families (SSC), simplex, } \\
858 \text { cases, } 863 \text { unaffected } \\
\text { sibs }\end{array}$ & $\begin{array}{l}\text { No significant difference } \\
\text { in frequency of inherited } \\
\text { CNVs in cases and controls }\end{array}$ & $\begin{array}{l}7.9 \% \text { in cases (median } \\
\text { genes per CNV: } 4 \text { ) } 2 \% \text { in } \\
\text { unaffected sibs (median } \\
\text { genes per CNV: } 0 \text { ) }\end{array}$ & $\begin{array}{l}\text { De novo: 16p11.2 (4 dup, } \\
6 \text { del); } 7 q 11.23 \text { (2 dup); } \\
\text { 16p13.2 (2 dup, } 1 \text { del); } 12 \\
\text { recurrent loci representing } \\
121 \text { events (data combined } \\
\text { with [52]) }\end{array}$ & DDX53-PTCHD1, USP7 \\
\hline
\end{tabular}

*Contains 1,340 overlapping probands and sibs with [20]. Del, deletions; dup, duplications.

mutations in cases than in controls, although there was an equal distribution of de novo missense mutations in this study. By combining genes that harbor frame-shift, splice-site, or nonsense de novo variants in cases across all four studies [22-25], five high-priority genes were identified that were disrupted in two independent probands: DYRK1A, POGZ, SCN2A, KATNAL2, and CHD8 (Table 1). There are several interesting lessons from these studies, including the utility of having data from other family members, which can help prioritize variants. One example is that the $\mathrm{Wnt} / \beta$-catenin signaling pathway was implicated in one study [22], but another that included a larger cohort of unaffected siblings [25] found that this pathway was over-represented in the unaffected siblings. These data suggest that more detailed pathway analysis is needed to understand the precise 
Table 3. Large-scale GWAS that reveal common and rare variants associated with ASD

\begin{tabular}{|c|c|c|c|c|}
\hline Reference & Stage & Families & Type & Most significant findings \\
\hline \multirow[t]{3}{*}{ Wang et al. 2009 [46] } & 1 & 780 families, 3,101 participants (AGRE) & Multiplex & $\begin{array}{l}\text { Top SNP rs } 4307059\left(\mathrm{p}=1.1 \times 10^{-5}\right)^{*} \text { between } \\
\text { CDH9 and CDH10; may disrupt a regulatory } \\
\text { non-coding RNA [158]. }\end{array}$ \\
\hline & 2 & 1,204 cases, 6,491 controls (ACC) & Case/control & Top SNP rs4307059 $\left(p=2.2 \times 10^{-4}\right)^{*}$ \\
\hline & 3 & Combined & & $\begin{array}{l}\text { GWS at rs } 4307059\left(p=3.4 \times 10^{-8} \text { combined }\right. \\
\text { with discovery cohorts; } p=2.1 \times 10^{-10} \\
\text { combined with replication cohorts) }\end{array}$ \\
\hline \multirow[t]{2}{*}{ Weiss et al. 2009 [47] } & 1 & $\begin{array}{l}\text { 1,031 families, 4,233 participants (AGRE, } \\
\text { NIMH) }\end{array}$ & Multiplex and simplex & $\begin{array}{l}\text { Top SNP rs } 10513025\left(p=1.7 \times 10^{-6}\right)^{*} \text { between } \\
\text { SEMASA and TAS2R1 }\end{array}$ \\
\hline & 2 & $\begin{array}{l}318 \text { trios (Boston Autism Consortium/ } \\
\text { Montreal), 1,755 trios (AGP, Finnish } \\
\text { families, Iranian trios) }\end{array}$ & Multiplex and simplex & $\begin{array}{l}\text { Top SNP rs } 10513025 ; p=2.1 \times 10^{-7 *} \\
\text { combining replication and scan data }\end{array}$ \\
\hline \multirow[t]{2}{*}{ Anney et al. 2010 [48] } & 1 & $\begin{array}{l}\text { 1,369 families (AGP), 1,385 cases(typically } \\
\text { only one proband genotyped per family) }\end{array}$ & Multiplex and simplex & $\begin{array}{l}\text { GWS at rs } 4141463\left(p=2.1 \times 10^{-8}\right) \text { in } \\
\text { MACROD2 (intronic) }\end{array}$ \\
\hline & 2 & 2,179 families (AGP group above/AGRE) & Multiplex and simplex & $\begin{array}{l}\text { GWS at rs } 4141463\left(p=4.7 \times 10^{-8}\right) \text { in } \\
\text { MACROD2 (intronic) }\end{array}$ \\
\hline
\end{tabular}

*Not genome-wide significant; GWS, genome-wide significant defined as $p<5 \times 10^{-8}$.

balance of signaling in this complex pathway [64] and its relationship to disease.

The study of RVs as ASD risk factors poses some challenges. Rarity does not indicate pathogenicity; rare events are seen in controls as well as in ASD participants, and inherited CNVs, by nature, will be present in the transmitting unaffected parent. In addition, a variant may be rare to the point of uniqueness for the sample sizes currently being studied, making causation difficult to establish and increasing the number of false negatives. Given these challenges, it is hard to determine which RVs are risk factors, which modulate risk, and which are unrelated to phenotype. The rarity of these events may preclude using traditional statistical techniques given that these techniques require a much larger sample to prove statistical association with disease [65]. Some reasonable statistical solutions are being developed [25].

One approach to elucidate the intersection of large candidate gene lists is to use systems biology techniques to incorporate our knowledge of protein interactomes. Towards this end, one group conducted network-based analysis of genetic associations (NETBAG) from a list of genes found to harbor de novo CNVs in individuals with ASD [20] and found a preponderance of network genes involved in neuronal motility, targeting of axons, and synapse development [66]. In addition, exome sequencing studies have found that proteins encoded by genes harboring de novo missense or nonsense mutations have a significantly enriched number of protein interactions [24] and form protein networks enriched for ASD candidate proteins that have specific molecular functions [22]. Another approach is to integrate genetic data with gene expression to identify $\mathrm{CNVs}$ that perturb gene expression, thus validating a functional effect. Such a study recently demonstrated the power of this method and identified several new potential ASD risk CNVs [59]. To fully understand the wealth of genomics data currently being generated, we will need both appropriate statistical techniques and bioinformatics approaches to identify significant points of convergence among candidate genes.

\section{Integrating genetic findings into a picture of ASD genetic architecture}

How do these findings inform our genetic models of disease? Several models have been put forth to explain the inheritance of ASDs. We discuss here the 'major effect model' and several polygenic models: a combination of CVs, a major effect RV in a background of CVs, a combination of RVs and CVs, and an oligogenic 'two hit' model (Figure 1). None of these are truly absolute and we expect that a wide range of genetic models will explain ASD in the individual [41].

The major effect model proposes that one major insult to the genome is sufficient for the disorder. This scenario is supported by the observation that disruptions of single genes can lead to ASD in an apparently Mendelian manner with reduced penetrance, as is seen in several syndromic forms of ASDs. For example, mutations in FMR1 (fragile X syndrome [43]), MECP2 (Rett Syndrome [67]), TSC1 and TSC2 (tuberous sclerosis [67]), CNTNAP2 (Cortical dysplasia-focal epilepsy syndrome [68]), DHCR7 (Smith-Lemli-Optiz syndrome [69]), CACNA1C (Timothy syndrome [70]) and PTEN [71] all result in syndromes with phenotypes overlapping those of ASDs 


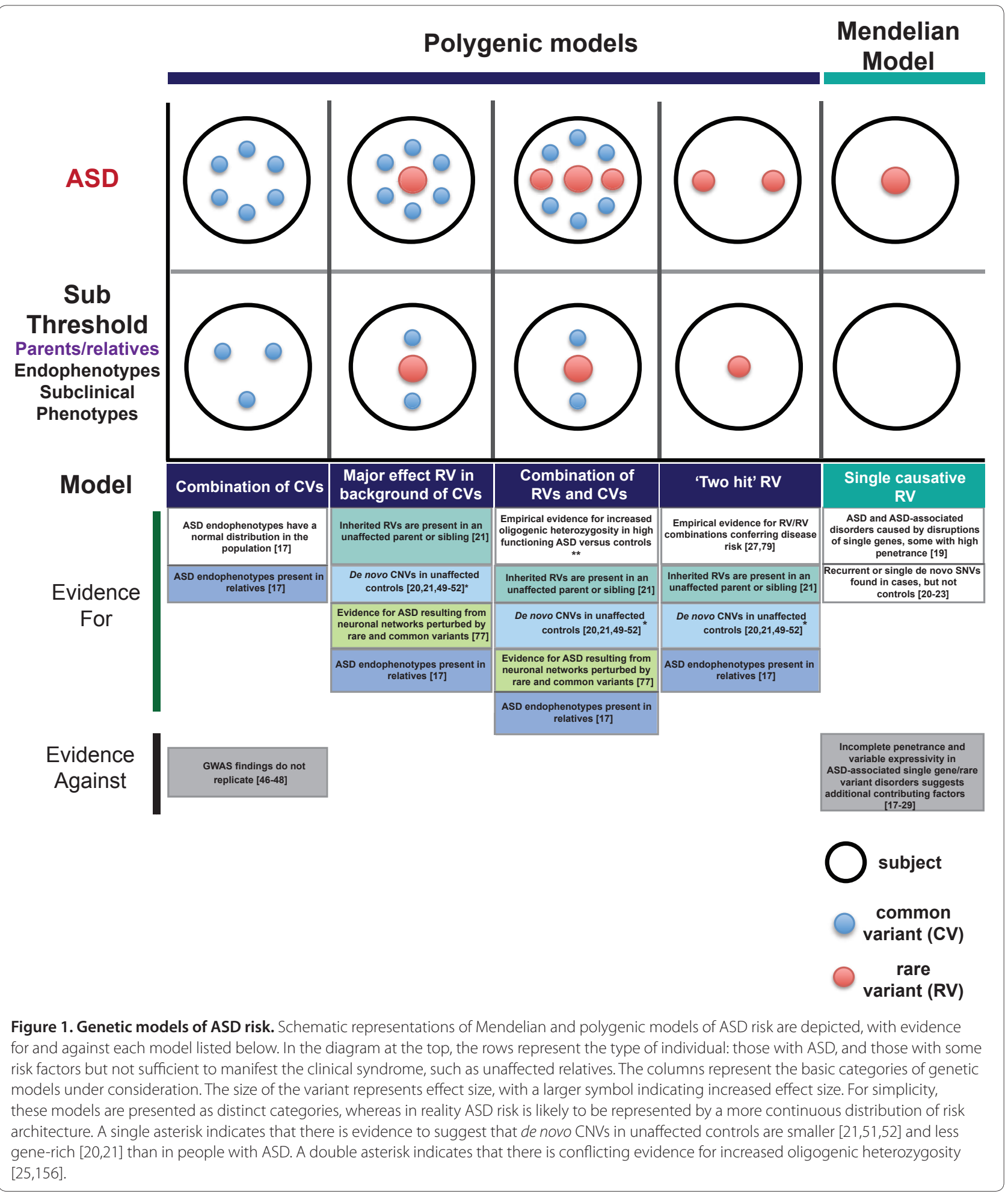

[17]. However, each of these syndromes show incomplete penetrance for ASD and variable expressivity. For example, $10 \%$ of people with FMR1 mutations do not show any ASD phenotype [23], and those who do express a wide range of phenotypes, with no more than $30 \%$ crossing a threshold for clinical diagnosis of ASD [72]. This incomplete penetrance and variable expressivity suggest that additional factors - genetic, epigenetic, and environmental - modulate the presence of ASD in someone with a major genetic disruption [41]. This pattern of 
highly variable expressivity should not be unexpected even with major effect alleles, as it has been observed frequently in dominantly inherited neurologic diseases, including a wide range of neurodegenerative diseases [73]. Additional examples of 'major hits' come from early cytogenetic studies, such as maternally inherited duplications of 15q11-15q13, deletions of 22q13, deletions of 2q37, and disruptions in 5p15, 17p11, and Xp22 [74].

An alternative to the major effect model is the polygenic model, in which various combinations of genetic variants in an individual lead to disease. Here, we highlight four non-exclusive polygenic models to illustrate the range of likely possibilities (Figure 1). In the first model, ASD results from a combination of CVs that exceed a tolerance threshold. In this model, relatives of ASD participants carry a subclinical genetic load of ASDassociated CVs. Evidence to support this model is that ASD endophenotypes are sometimes observed in relatives, suggesting that subsets of CV combinations are sufficient for endophenotypes [17]. In addition, several ASD endophenotypes have a normal distribution in the population, which would be predicted by multiple contributory factors of modest to low effect [41].

The second and third polygenic models (Figure 1) are an RV in a genetic milieu of CVs that results in ASD when the load of CVs is sufficient to exceed an arbitrary threshold and a combination of RVs and CVs of various effect sizes that exceed a threshold of tolerance. Shared lines of support for both models are that (i) ASD risk factors, such as 15q11-15q13 [75] and 16p11.2 [76], that are rare inherited disruptions are present in both the unaffected parent and the affected offspring, suggesting that additional genetic modifiers are needed to confer disease risk; (ii) de novo CNVs are found in both cases and unaffected controls, again suggesting that additional genetic modifiers are needed for disease state or that some of these variants do not contribute to disease state; (iii) neuronal networks identified by bioinformatic analysis of transcriptome data are enriched for ASDassociated common and RVs [77]; and (iv) ASD-related component phenotypes are present in relatives owing to sub-threshold loading of common and RVs. Additional support for the polygenic models comes from the observation that even rare, de novo nonsense and splicesite mutations increase the odds of ASD by an average of only 6 fold $[23,25]$. This probably represents a large range of genotype risk, but suggests that many rare deleterious mutations are not alone sufficient to cause ASD.

A fourth form of the polygenic model (Figure 1) involves two hits, wherein one RV is tolerated but two hits leads to a disease state, similar to cancer [78]. Some examples of this model have been presented [27,79], and the model is consistent with inherited RVs being present in the transmitting parent (discussed above), de novo
$\mathrm{CNVs}$ being found in unaffected controls, and relatives manifesting sub-threshold ASD traits. However, a two hit model is probably not the predominant cause based on recent exome data [22-25] and, even in cancer, where this model originated, a more continuous model of genetic contribution is now supported [78]. Taken together, there is the greatest support for a more continuous, and highly heterogeneous, polygenic model in which ASD results from a combination of RVs and CVs that build to exceed a clinical threshold in many different combinations in the population.

\section{Emerging biological themes}

ASD genes fall into many potential functional classes; this heterogeneity raises the question of how such diverse mechanisms lead to ASD. To answer this question, it is critical to identify the points of potential convergence among autism candidate genes in developmental and anatomical terms. Toward this end, expression patterns of ASD genes have been annotated using whole-genome transcriptome profiling in blood and brain from ASD and control participants [54]. At the same time, large efforts have been made to build proteomic interactomes of autism candidate genes $[22,24,80]$ so as to understand how these molecules functionally intersect. These efforts have been concurrent with the development of large protein and RNA expression databases that provide genome-wide spatial and temporal expression information (the Allen Brain Atlas [81], Gene Paint [82], the Cerebellar Development Transcriptome Database [83], the Ref-Seq Atlas [84], the Human Protein Reference Database $[85,86]$, the NIA mouse protein-protein interaction database [87], and the Genes to Cognition database [88]).

Definitive demonstration of convergence will require experiments testing causality in model systems. Currently, there are several vertebrate and invertebrate systems, including Drosophila [89-91], zebrafish [58], and the mouse, that provide a tractable genetic and neurobiological systems for understanding the biological impact of specific susceptibility from the molecular to the complex behavioral level. Most modeling has been done in the mouse, in which many of the complex behaviors involved in autism can be tested, including social responsiveness [92]. However, given that the common ancestor of mouse and human is separated by 60 million years of evolution, it is not a foregone conclusion that disruption of a gene or genes that cause ASD in humans will lead to similar behaviors in mouse. There is little known about the parallels between neural systems serving social cognition and communication in mouse and human. So, it is reasonable to start without many preconceived assumptions and view the mouse, similar to the fly or zebrafish, as a genetically sensitized system for 
exploring the molecular, cellular, and circuit-level mechanisms of ASD-related genetic variation.

Crawley and colleagues [92] have elegantly outlined three basic levels of model validity: (i) construct validity (the model contains the same biological perturbation as the human disorder, for instance genetic or anatomical); (ii) face validity (the model displays endophenotypes or phenotypes that mirror the human disorder); and (iii) predictive validity (the model has a similar response to treatments effective in humans). Using this construct, it is remarkable that several ASD-associated genetic variants have recapitulated many human ASD endophenotypes when modeled in a mouse, including Cntnap2 knockout (language, restrictive/repetitive, and social domains) [93], Nlgn4 knockout (language and social) [94], En2 knockout (restrictive/repetitive and social) [95,96], 15q11-13 duplication; chromosome 7 in mouse (language, restrictive/repetitive, and social) [97], Gabrb3 knockout (restrictive/repetitive and social) [98], Oxt knockout (language and social) [99-101], Avpr1b knockout (language and social) [102,103], and Fgf17 knockout (language and social) [104]. Inbred strains of mice, such as BTBR, BALB, and C58/J, also show ASD endophenotypes [92]. However, it is unclear exactly how a behavior in mouse, such as deficits in ultrasonic vocalization, translates into a human phenotype, such as language delay. Indeed, disparity in the molecular, anatomical, and neuronal circuitry between mouse and humans is likely and must be interpreted with caution. Keeping these caveats in mind, modeling of ASD variants in mouse is proving to be an exceptionally useful tool in understanding potential ASD mechanisms. It is hoped that combining mouse models and in vitro models will facilitate finding convergence points, especially at the molecular level, and will provide a tractable avenue for pharmaceutical intervention. Here, we touch on these areas of intersection at the molecular, cellular, systems, and neuroanatomical level and discuss progress toward integration across levels.

\section{Neuronal activity and ASDs}

One potential point of convergence developing from gene finding studies is that autism pathophysiology involves proteins that both modulate neuronal activity and show activity-dependent expression (Figure 2f). Of the handful of proteins identified by whole-exome sequencing reviewed above, $S C N 2 A, S C N 1 A$, and GRIN2B all code for subunits of synaptic ion channels, with $S C N 2 A$ and SCN1A coding for the $\alpha$ subunits of voltage-gated sodium channels [22,25]. GRIN2A, an N-methyl-D-aspartate (NMDA) receptor subunit mapping within the 16p11-13 region, was additionally identified in a largescale ASD association study [105]. NMDA receptors are ionotropic ion channels that are critical regulators of activity-dependent synaptic plasticity. Other notable ASD candidate genes that code for ion channels are the ionotropic glutamate receptors GRIK2 [106] and GRIA3 [107] and the voltage-dependent calcium channel subunits CACNA1C [70] and CACNA1H [108].

ASD candidate genes are also enriched in sets of transcripts regulated by neuronal activity (Figure 2f). For example, UBE3A [21,109], DIA1 [110], and PCDH10 [110] are all regulated by MEF2A/D, a transcription factor that has a major role in activity-dependent development of the synapse [111]. Moreover, the autism candidate gene NHE9 is regulated by NPAS4, a transcription factor regulated by neuronal activity [110]. Lastly, a recent study identified ASD candidate genes UBE3B, CLTCL1, NCKAP5L, and ZNF18 by whole-exome sequencing and found their expression to be regulated by neuronal depolarization [112]. In sum, these results point to a potential contribution of genes regulated by or regulating neuronal activity to autism pathophysiology.

\section{Post-synaptic translational regulation}

Another potential point of molecular convergence in autism genetics is activity-dependent protein metabolism at the postsynaptic density (PSD), a protein-rich specialization at the postsynaptic membrane critical for effective neural transmission (Figure 2e). Single gene disorders that intersect with ASD gave us first clues that this process is important in the pathophysiology of autism. Mutations in FMR1, the leading inherited cause of ASD [113], results in the absence of Fragile X mental retardation protein (FMRP), a key regulator of activity-dependent protein synthesis at the synapse [114]. FMRP-mediated translation is regulated in an activity-dependent manner by the autism candidate gene, CYFIP1, located within the 15q11-13 duplication region [115]. Recently, wholeexome studies have reported an enrichment of FMRPassociated genes in the lists of genes disrupted by RVs in ASD participants [23]. FMRP is associated with the autism candidate genes MET [116], PTEN, TSC1, TSC2 and NF1 [117], which are also located within the PSD [118-120]. These genes are part of the phosphatidylinositol 3-kinase (PI3K)-AKT-mTOR pathway which is activated by metabotropic glutamate receptor signaling $[119,121]$, is an upstream effector of translation regulation, and is involved in cellular proliferation [122]. Individuals with RVs in several of these genes have been found in the large gene finding studies outlined above (PTEN [22], TSC [22], MET [21], NF1 [21]), and additional regulators of protein translation have been identified (RPL10 [21]).

Ubiquitination pathways, which regulate protein metabolism at the PSD, are also associated with autism (Figure 2e). Most notably, UBE3A, a protein implicated in the ASD-associated disorder Angelman's syndrome [17], 
(a)

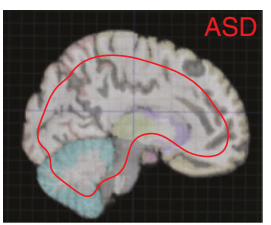

Birth
Brain growth

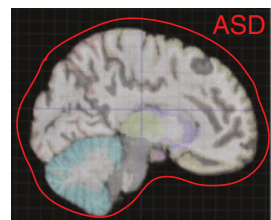

Postnatal

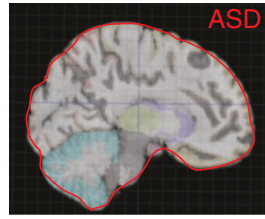

Adolescence

ASD associated molecular pathways: PI3K-AKT-mTOR

(c)

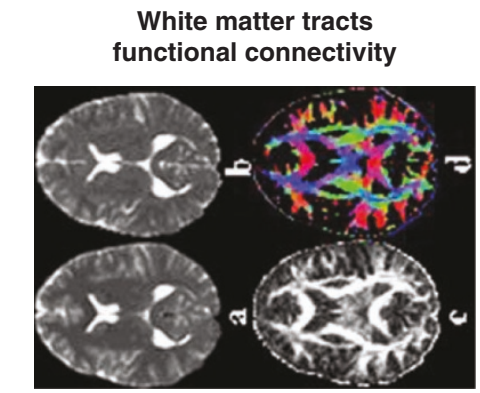

ASD-associated genes: CNTNAP2, MET (b)

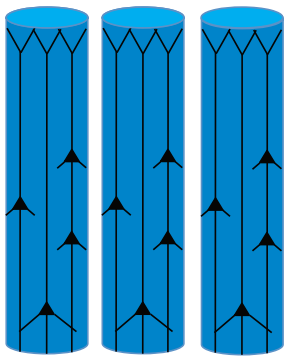

Normal
Cortical columns

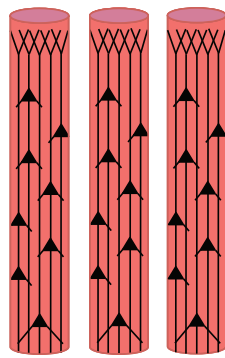

ASD

(d)

Balance of excitation/inhibition

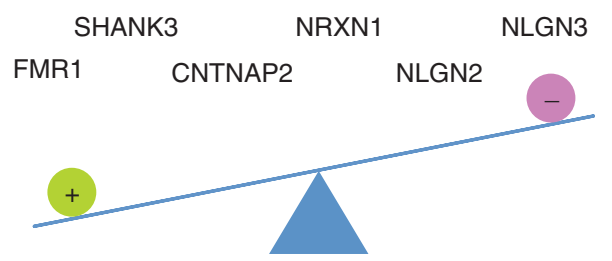

(e)

Activity-dependent protein synthesis

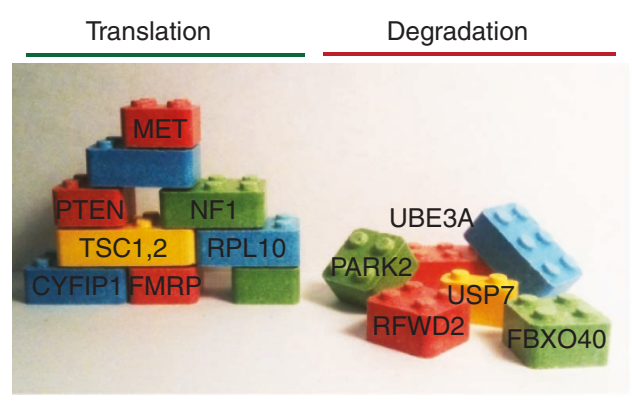

(f)

Neuronal activity

(g)

Neuronal cell adhesion
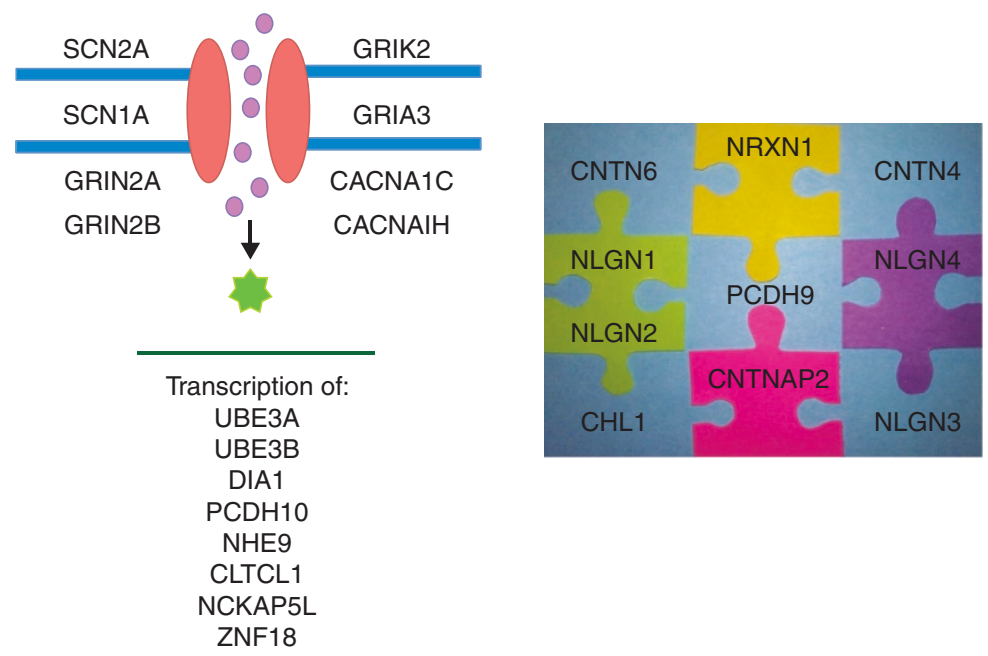

Figure 2. Emerging biological themes in ASD. $(\mathbf{a}, \mathbf{b})$ Predominant areas of neuroanatomical convergence in ASD. (a) Aberrant brain growth trajectories, with the size of ASD brains outlined in red against a background of normal brains [144-146] (images adapted from [157]); (b) abnormal cortical columns [151]. (c,d) Systems-level convergence in ASD. (c) White matter tract and functional connectivity abnormalities [126,147-150,152,153] (images reproduced with permission from Mark Bastin, University of Edinburgh, UK); (d) excitation/inhibition network imbalances [93,132,136-141], (e-g) Genetic convergence at the cellular and molecular levels. ASD-associated genes implicated in (e) activity-dependent protein synthesis [17,21,23,79,109,113-123], (f) neuronal activity [21,22,25,70,105-112], and (g) neuronal cell adhesion $[20-22,34-37,49-52,68,75,79,93,109,126-129,131-137]$

is involved in ubiquitination of its target proteins, such as the FMRP translational target $A R C$ [123], which leads to their degradation at excitatory postsynaptic densities. RVs in $U B E 3 A$ and genes encoding associated proteins have been found in recent large-scale $\mathrm{CNV}$ studies
(UBE3A, PARK2, RFWD2, and FBXO4O [109]; USP7 and UBE3A [21]).

Although not directly involved in protein metabolism, another large group of ASD proteins converge at excitatory postsynaptic densities. The most notable are the 
synaptic scaffolding proteins SHANK2 and SHANK3, identified as ASD risk factors in several studies [27,52, 124,125]. Recently, an autism protein interactome built using a human yeast two-hybrid screen and 35 ASDimplicated proteins as bait found that a large group of PSD-localized ASD-associated proteins interact. This study additionally confirmed the SHANK3-PSD95 interaction, added nine additional protein binding partners to this interaction, and identified novel PSD interactions such as the SHANK3-TSC1-ACTN1HOMER3 interaction [80]. In sum, these data point to the excitatory PSD as a hot spot for ASD-associated molecules, making it a potential target for drug discovery.

\section{Neuronal cell adhesion}

ASD-associated mutations in several proteins involved in cell adhesion include CNTNAP2, CNTN4, CNTN6, NLGN1-4, NRXN1, PCDH9, and CHL1 (Figure 2g). Multiple converging lines of evidence implicate CNTNAP2 in ASD pathology, including its role in a syndromic form of autism [68], variants found in linkage and association studies [35-37], presence of RVs [79], its impact in functional magnetic resonance imaging (MRI) readouts in humans [126], and molecular evidence that its knockout leads to the behavioral manifestation of all three core domains of autism as well as neuronal migration abnormalities [93]. A member of the neurexin superfamily, CNTNAP2 is involved in cell-cell adhesion, clustering of potassium channels at the juxtaparanode [127], neuronal migration, and regulation of GABAergic interneuron numbers [93]. There are data to support an additional contactin family member, CNTN4, in autism pathophysiology $[109,128,129]$, although this has been recently challenged [130]. CNTN6 has also been implicated by CNV studies [20,49-52,75,109,131]. Neurexins and neuroligins have both been heavily implicated in ASD pathophysiology. Neurexins are located presynaptically and bind to postsynaptically localized neuroligins. These molecules modulate both excitatory and inhibitory synaptic function [132]. NRXN1 has been identified as an ASD risk factor by cytogenetic analysis [133], large-scale CNV studies [21,50,109], and case reports [34]. NLGN1, NLGN3 and NLGN4 have also been identified in several studies [21,22,109,134,135], and CNTNAP2 is homologous to Drosophila Neurexin 4 [89]. Additional evidence for the role of NLGNS and NRXN1 in ASD involves introduction of ASDassociated variants, knockout, or overexpression of these proteins in mouse models. These studies have recapitulated various aspects of the ASD phenotype $[132,136,137]$ and have additionally implicated NLGN2. PCDH9 and CHL1 may also contribute to ASD based on CNV studies [20,49-52,75,109,131].

\section{Balancing excitation and inhibition}

Functional studies in mouse models have suggested that some of the ASD candidates contribute to network dynamics by altering the balance of excitation and inhibition (Figure 2d). For example, a slight increase in levels of NLGN2 in mouse reduces the excitation to inhibition ratio by decreasing the ratio of excitatory to inhibitory synapses, increasing inhibitory synaptic contacts, and increasing the frequency of miniature inhibitory PSCs in the frontal cortex [132]. In addition, introducing the ASD-associated NLGN3 missense mutation into a mouse increases inhibitory function in cortex [136]. Similarly, Nrxn1a knockout mice exhibit a decrease in hippocampal excitatory function [137]. Knocking out Cntnap2 in a mouse reduces cortical GABAergic interneuron numbers, potentially altering the balance of excitation and inhibition [93]. In addition, Shank3 knockout decreases cortical excitatory transmission [138]. Fmr1 knockout mice show several excitatory/inhibitory imbalances, including impaired inhibitory transmission in the amygdala [139], decreased excitatory inputs into inhibitory neurons in the cortex [140], and an increased inhibitory transmission in the striatum [141].

There is corroborating data for the role of excitation and inhibition in autism from whole transcriptome studies of human postmortem brain. One recent study used a sophisticated systems biology approach, weighted gene co-expression network analysis (WGCNA), to build transcriptome networks from human ASD and control postmortem brain samples [142]. The top autism associated WGCNA network, enriched for ASD-associated GWAS targets, showed high overlap with a previously identified interneuron-related module [143]. Understanding how perturbations in this delicate balance of excitation and inhibition lead to disease will be crucial in understanding ASD pathophysiology. Considerations in this endeavor will include a clear understanding of how deficits affect both microcircuits and more long distance connectivity.

\section{Connecting convergent molecular pathways with higher-order ASD phenotypes}

Effective drug design would be facilitated by convergence at the level of molecular pathways. However, convergence at higher levels is also plausible. In fact, some of the most reproducible clinical signatures have been at the level of brain structure and function. For example, the trajectory of head growth, which corresponds to brain size, seems to be reproducibly abnormal in children with ASD, who have smaller head circumferences at birth followed by a burst in head circumferences postnatally, eventually reaching normal size around adolescence (Figure 2a) [144-146]. Studies have also repeatedly shown decreases in white matter tracts in autism (Figure 2c) $[147,148]$. 
Specifically, long-range connections seem to be weakened, whereas local connections are strengthened $[149,150]$. Cortical structure abnormalities, specifically denser and narrower cortical columns, have also been reported (Figure 2b) [151], and functional MRI neural signatures for autism are being defined [126,152,153].

Even if the point of convergence is at the molecular level, how do we connect these findings with those at the macroscopic level, described here? Some salient examples are worth noting. As discussed above, the PI3K-AKTmTOR pathway is strongly enriched for ASD candidate genes. This pathway affects cellular proliferation, which could, in theory, lead to the abnormal brain growth reported in autism (Figure $2 \mathrm{a}$ ). However, elucidating the 'dark matter' between this molecular pathway and brain size will not be trivial. Another example involves the link between activity-dependent brain specializations during early postnatal development and molecular pathways that rely heavily on neuronal activity, described as a point of molecular convergence above. A recent study reported a failure of frontal and temporal cortical specialization in autism brains as defined by transcriptome signatures [142]. This could be a result of disruptions in activitydependent molecular pathways needed at critical developmental times. Nevertheless, connecting the dots between different levels of analysis will be a formidable task.

One proof of principle model involves the gene CNTNAP2 [154]. The ramifications of genetic perturbations in this gene have been studied on multiple levels, spanning molecular studies, mouse models, and functional MRI studies. A thorough examination of implicated pathways from molecules to brain structure will need to be conducted to integrate our understanding of autism pathophysiology across levels.

\section{Future directions}

The combination of worldwide collaborative data and sample sharing with advanced genomic techniques and bioinformatic strategies has provided the essential foundation for uncovering the genetic and molecular underpinnings of ASD. The contributory genes uncovered in the past 5 years have led to a revolution in our understanding of the disorder. Not surprisingly, the near future is highly focused on whole-genome and whole-exome sequencing of large patient cohorts, which is facilitated by continuing technological advances that reduce cost barriers.

The major obvious questions raised by this approach are: what degree of insight will be obtained and what advantages will whole-genome sequencing provide over whole-exome sequencing? Given the role of gene dosage changes, implicated by CNV [59], and evidence for splicing dysregulation in ASD [142], one should expect a significant contribution of non-coding, regulatory changes to ASD susceptibility. Thus, we envision a significant advance once whole-genome sequencing can be performed cost-effectively in large cohorts. At the same time, exome sequencing is predicted to yield dozens of new ASD genes, so it remains a productive short-term approach [22-25]. Large population cohorts, perhaps using clinical sequencing rather than investigator-organized research cohorts, provide one avenue for comprehensive genetic evaluation in the necessary number of participants in an efficient manner, despite many potential barriers [155].

One notable absence in this discussion has been linkage analysis, perhaps raising the question: is genetic linkage dead in the age of genome sequencing? Few linkage peaks have been identified and replicated and dense SNP analysis of linkage peaks has not revealed common variation accounting for the linkage signal [17]. Thus, replicated linkage peaks are probably signals for aggregation of RVs. Given the emergence of RVs as factors in ASD susceptibility, genetic linkage, especially using quantitative trait approaches [29], probably provides a reasonable means for restricting the search space for ASD risk variants and assessing their segregation in families.

The next crucial issue is how to validate the pathogenicity of identified variants, especially non-coding SNVs. We envision that associated variants from these studies will be prioritized on the basis of their ability to be translated into tractable models of disease. A clear limitation is that associated variants may be found in poorly annotated non-coding regions. It has often been thought that non-coding variants are harder to functionally annotate, but in some ways they may prove more tractable to assess in high throughput. For example, it can be a very long road to understanding the effect of a missense mutation in a protein of known or unknown function. In contrast, many variants found in poorly annotated non-coding regions can be tested for cis or trans effects on gene expression, first in expression quantitative trait locus datasets and then in neuronal cell culture or in mouse models. As genome function becomes more densely annotated, the ease of such analyses will further increase. Thus, although there still remain major challenges in variant identification and initial assessment of their pathogenicity, these can be largely overcome by technology and greater numbers. However, phenotype definition and understanding what specific aspects of the broad ASD phenotype relate to individual genetic risk factors remains only superficially explored and will continue to be a major roadblock for those interested in understanding biological mechanisms of disease.

Now that significant contributions to genetic risk for ASD have been uncovered, it behooves us to perform parallel phenotypic analyses at multiple levels in humans 
and model systems to understand the mechanisms of diverse forms of major contributory mutations. For example, understanding what a group of a dozen syndromic forms of ASD have in common and what distinguishes their phenotypes from a molecular, cellular, and cognitive standpoint would be informative. Furthermore, combining information on chromatin structure and epigenetic modification to sequence data may reveal environmental contributions and their potential intersection with known genetic risks. In this manner, combining various forms of high-throughput data and pathway analyses with multiple levels of phenotype data in well-studied cohorts is likely to be necessary to deepen our understanding of ASD pathophysiology. Despite the extraordinary genetic heterogeneity revealed by recent studies, various forms of high-throughput data and pathway analyses discussed here have provided evidence of biological convergence. As our understanding of genetic contributions to ASD expands from the current dozens of genes into the hundreds from ongoing human genetic studies, the notion of biological convergence can be tested more rigorously. Furthermore, because even RVs on average have intermediate effects with regard to ASD risk, exploration of potential epistatic interactions between loci may contribute to a clearer picture of the landscape of ASD genetics. In the mean time, these new genetic findings from the last few years provide us with a starting point to explore the first generation of genetically targeted therapeutics in ASD.

\section{Abbreviations}

ACE, Autism Center of Excellence; ADHD, attention deficit hyperactivity disorder; AGP, Autism Genome Project; AGRE, Autism Genetic Resource Exchange; ASD, autism spectrum disorder; CNV, copy number variation; CV, common variant; FMRP, Fragile X mental retardation protein; GWAS, genome-wide association study; MRI, magnetic resonance imaging; NMDA, N-methyl-D-aspartate; OR, odds ratio; PI3K, phosphatidylinositol 3-kinase; PSD, postsynaptic density; RV, rare variant; SNP, single nucleotide polymorphism; SNV, single nucleotide variant; SSC, Simons Simplex Collection; WGCNA, weighted gene co-expression network analysis.

\section{Competing interests}

The authors declare that they have no competing interests

\section{Acknowledgements}

Our work in autism is supported by grants NIMH F31 MH088083 (JMB); NIH T32 MH073526 (JMB); UCLA Chancellor's Award (JMB); Achievement Rewards for College Scientists (JMB); Autism Center of Excellence Network grant NIH/ NIMH R01 MH081754 (DHG); Autism Center of Excellence Center Grant NIH/ NICHD P50HD055784 (DHG); Simons Foundation and Autism Speaks.

\section{Author details}

'Program in Neuroscience IDP, David Geffen School of Medicine, University of California, Los Angeles, CA 90095, USA. ${ }^{2}$ Semel Institute for Neuroscience and Human Behavior, University of California, Los Angeles, CA 90095, USA. 3Program in Neurogenetics, Department of Neurology, David Geffen School of Medicine, University of California, Los Angeles, CA 90095, USA. ${ }^{4}$ Center for Autism Research and Treatment and Center for Neurobehavioral Genetics, Semel Institute for Neuroscience and Human Behavior, University of California, Los Angeles, CA 90095, USA.

Published: 31 July 2012
References

1. Bill BR, Geschwind DH: Genetic advances in autism: heterogeneity and convergence on shared pathways. Curr Opin Genet Dev 2009, 19:271-278.

2. Kanner L: Autistic disturbances of affective contact. Nerv Child 2 1943:217-250

3. American Psychiatric Association: Diagnostic and statistical manual of mental disorders. 4th ed., text rev. American Psychiatric Association; 2000.

4. Geschwind DH: Advances in autism. Annu Rev Med 2009, 60:367-380.

5. Tuchman R, Rapin I: Epilepsy in autism. Lancet Neurol 2002, 1:352-358

6. Chakrabarti S, Fombonne E: Pervasive developmental disorders in preschool children: confirmation of high prevalence. Am J Psychiatry 2005, 162:1133-1141.

7. Centers for Disease Control and Prevention: Autism and Developmental Disabilities Monitoring Network, 2012 [http://www.cdc.gov/ncbddd/ autism/documents/ADDM-2012-Community-Report.pdf]

8. Volk HE, Hertz-Picciotto I, Delwiche L, Lurmann F, McConnell R: Residential proximity to freeways and autism in the CHARGE study. Environ Health Perspect 2011, 119:873-877.

9. Hertz-Picciotto I, Delwiche L: The rise in autism and the role of age at diagnosis. Epidemiology 2009, 20:84-90.

10. King M, Bearman P: Diagnostic change and the increased prevalence of autism. Int J Epidemio/ 2009, 38:1224-1234.

11. Cantor RM, Yoon JL, Furr J, Lajonchere CM: Paternal age and autism are associated in a family-based sample. Mol Psychiatry 2007, 12:419-421.

12. Hallmayer J, Cleveland S, Torres A, Phillips J, Cohen B, Torigoe T, Miller J, Fedele A, Collins J, Smith K, Lotspeich L, Croen LA, Ozonoff S, Lajonchere C, Grether JK, Risch N: Genetic heritability and shared environmental factors among twin pairs with autism. Arch Gen Psychiatry 2011, 68:1095-1102.

13. Rosenberg RE, Law JK, Yenokyan G, McGready J, Kaufmann WE, Law PA: Characteristics and concordance of autism spectrum disorders among 277 twin pairs. Arch Pediatr Adolesc Med 2009, 163:907-914

14. Ozonoff S, Young GS, Carter A, Messinger D, Yirmiya N, Zwaigenbaum L, Bryson S, Carver LJ, Constantino JN, Dobkins K, Hutman T, Iverson JM, Landa R, Rogers SJ, Sigman M, Stone WL: Recurrence risk for autism spectrum disorders: a Baby Siblings Research Consortium study. Pediatrics 2011, 128:e488-e495.

15. Zhao X, Leotta A, Kustanovich V, Lajonchere C, Geschwind DH, Law K, Law P, Qiu S, Lord C, Sebat J, Ye K, Wigler M: A unified genetic theory for sporadic and inherited autism. Proc Natl Acad Sci USA 2007, 104:12831-12836.

16. Constantino JN, Todorov A, Hilton C, Law P, Zhang Y, Molloy E, Fitzgerald R, Geschwind D: Autism recurrence in half siblings: strong support for genetic mechanisms of transmission in ASD. Mol Psychiatry 2012, doi: 10.1038/mp.2012.9.

17. Abrahams BS, Geschwind DH: Advances in autism genetics: on the threshold of a new neurobiology. Nat Rev Genet 2008, 9:341-355.

18. Schaaf CP, Zoghbi HY: Solving the autism puzzle a few pieces at a time. Neuron 2011, 70:806-808.

19. Bourgeron $\mathrm{T}$ : The possible interplay of synaptic and clock genes in autism spectrum disorders. Cold Spring Harb Symp Quant Biol 2007, 72:645-654.

20. Levy D, Ronemus M, Yamrom B, Lee YH, Leotta A, Kendall J, Marks S, Lakshmi B, Pai D, Ye K, Buja A, Krieger A, Yoon S, Troge J, Rodgers L, lossifov I, Wigler M: Rare de novo and transmitted copy-number variation in autistic spectrum disorders. Neuron 2011, 70:886-897.

21. Sanders SJ, Ercan-Sencicek AG, Hus V, Luo R, Murtha MT, Moreno-De-Luca D, Chu SH, Moreau MP, Gupta AR, Thomson SA, Mason CE, Bilguvar K, CelestinoSoper PB, Choi M, Crawford EL, Davis L, Wright NR, Dhodapkar RM, DiCola M, DiLullo NM, Fernandez TV, Fielding-Singh V, Fishman DO, Frahm S, Garagaloyan R, Goh GS, Kammela S, Klei L, Lowe JK, Lund SC, et al:: Multiple recurrent de novo CNVs, including duplications of the $7 q 11.23$ Williams syndrome region, are strongly associated with autism. Neuron 2011, 70:863-885.

22. O'Roak BJ, Vives L, Girirajan S, Karakoc E, Krumm N, Coe BP, Levy R, Ko A, Lee C, Smith JD, Turner EH, Stanaway IB, Vernot B, Malig M, Baker C, Reilly B, Akey JM, Borenstein E, Rieder MJ, Nickerson DA, Bernier R, Shendure J, Eichler EE.: Sporadic autism exomes reveal a highly interconnected protein network of de novo mutations. Nature 2012, 485:246-250.

23. Iossifov I, Ronemus M, Levy D, Wang Z, Hakker I, Rosenbaum J, Yamrom B, Lee YH, Narzisi G, Leotta A, Kendall J, Grabowska E, Ma B, Marks S, Rodgers L, Stepansky A, Troge J, Andrews P, Bekritsky M, Pradhan K, Ghiban E, Kramer M, Parla J, Demeter R, Fulton LL, Fulton RS, Magrini VJ, Ye K, Darnell JC, Darnell RB, et al:: De novo gene disruptions in children on the autistic spectrum. 
Neuron 2012, 74:285-299

24. Neale BM, Kou Y, Liu L, Ma'ayan A, Samocha KE, Sabo A, Lin CF, Stevens C, Wang LS, Makarov V, Polak P, Yoon S, Maguire J, Crawford EL, Campbell NG, Geller ET, Valladares O, Schafer C, Liu H, Zhao T, Cai G, Lihm J, Dannenfelser R, Jabado O, Peralta Z, Nagaswamy U, Muzny D, Reid JG, Newsham I, Wu Y, et al:: Patterns and rates of exonic de novo mutations in autism spectrum disorders. Nature 2012, 485:242-245.

25. Sanders SJ, Murtha MT, Gupta AR, Murdoch JD, Raubeson MJ, Willsey AJ, Ercan-Sencicek AG, DiLullo NM, Parikshak NN, Stein JL, Walker MF, Ober GT, Teran NA, Song Y, El-Fishawy P, Murtha RC, Choi M, Overton JD, Bjornson RD, Carriero NJ, Meyer KA, Bilquvar K, Mane SM, Sestan N, Lifton RP, Günel M, Roeder K, Geschwind DH, Devlin B, State MW: De novo mutations revealed by whole-exome sequencing are strongly associated with autism. Nature 2012, 485:237-241.

26. State MW, Levitt $P$ : The conundrums of understanding genetic risks for autism spectrum disorders. Nat Neurosci 2011, 14:1499-1506.

27. Leblond CS, Heinrich J, Delorme R, Proepper C, Betancur C, Huguet G, Konyukh M, Chaste P, Ey E, Rastam M, Anckarsäter H, Nygren G, Gillberg IC, Melke J, Toro R, Regnault B, Fauchereau F, Mercati O, Lemière N, Skuse D, Poot M, Holt R, Monaco AP, Järvelä I, Kantojärvi K, Vanhala R, Curran S, Collier DA, Bolton P, Chiocchetti A, et al:: Genetic and functional analyses of SHANK2 mutations suggest a multiple hit model of autism spectrum disorders. PLoS Genet 2012, 8:e1002521.

28. Girirajan S, Brkanac Z, Coe BP, Baker C, Vives L, VuTH, Shafer N, Bernier R, Ferrero GB, Silengo M, Warren ST, Moreno CS, Fichera M, Romano C, Raskind WH, Eichler EE: Relative burden of large CNVs on a range of neurodevelopmental phenotypes. PLoS Genet 2011, 7:e1002334

29. Geschwind DH: Genetics of autism spectrum disorders. Trends Cogn Sci 2011, 15:409-416

30. Arguello PA, Gogos JA: Genetic and cognitive windows into circuit mechanisms of psychiatric disease. Trends Neurosci 2012, 35:3-13.

31. Malhotra D, Sebat J: CNVs: harbingers of a rare variant revolution in psychiatric genetics. Cell 2012, 148:1223-1241.

32. Guilmatre A, Dubourg C, Mosca AL, Legallic S, Goldenberg A, Drouin-Garraud V, Layet V, Rosier A, Briault S, Bonnet-Brilhault F, Laumonnier F, Odent S, Le Vacon G, Joly-Helas G, David V, Bendavid C, Pinoit JM, Henry C, Impallomeni C, Germano E, Tortorella G, Di Rosa G, Barthelemy C, Andres C, Faivre L, Frébourg T, Saugier Veber P, Campion D: Recurrent rearrangements in synaptic and neurodevelopmental genes and shared biologic pathways in schizophrenia, autism, and mental retardation. Arch Gen Psychiatry 2009, 66:947-956

33. Girirajan $\mathrm{S}$, Campbell CD, Eichler EE: Human copy number variation and complex genetic disease. Annu Rev Genet 2011, 45:203-226.

34. Zahir FR, Baross A, Delaney AD, Eydoux P, Fernandes ND, Pugh T, Marra MA, Friedman JM: A patient with vertebral, cognitive and behavioural abnormalities and a de novo deletion of NRXN1 alpha. J Med Genet 2008 45:239-243.

35. Alarcón M, Abrahams BS, Stone JL, Duvall JA, Perederiy JV, Bomar JM, Sebat J, Wigler M, Martin CL, Ledbetter DH, Nelson SF, Cantor RM, Geschwind DH: Linkage, association, and gene-expression analyses identify CNTNAP2 as an autism-susceptibility gene. Am J Hum Genet 2008, 82:150-159.

36. Bakkaloglu B, O'Roak BJ, Louvi A, Gupta AR, Abelson JF, Morgan TM, Chawarska K, Klin A, Ercan-Sencicek AG, Stillman AA, Tanriover G, Abrahams BS, Duvall JA, Robbins EM, Geschwind DH, Biederer T, Gunel M, Lifton RP, State MW: Molecular cytogenetic analysis and resequencing of contactin associated protein-like 2 in autism spectrum disorders. Am J Hum Genet 2008, 82:165-173.

37. Arking DE, Cutler DJ, Brune CW, Teslovich TM, West K, Ikeda M, Rea A, Guy M, Lin S, Cook EH, Chakravarti A: A common genetic variant in the neurexin superfamily member CNTNAP2 increases familial risk of autism. Am J Hum Genet 2008, 82:160-164.

38. Friedman JI, Vrijenhoek T, Markx S, Janssen IM, van der Vliet WA, Faas BH, Knoers NV, Cahn W, Kahn RS, Edelmann L, Davis KL, Silverman JM, Brunner HG, van Kessel AG, Wijmenga C, Ophoff RA, Veltman JA: CNTNAP2 gene dosage variation is associated with schizophrenia and epilepsy. Mol Psychiatry 2008, 13:261-266.

39. Elia J, Gai X, Xie HM, Perin JC, Geiger E, Glessner JT, D'arcy M, deBerardinis R, Frackelton E, Kim C, Lantieri F, Muganga BM, Wang L, Takeda T, Rappaport EF, Grant SF, Berrettini W, Devoto M, Shaikh TH, Hakonarson H, White PS: Rare structural variants found in attention-deficit hyperactivity disorder are preferentially associated with neurodevelopmental genes. Mol Psychiatry
2010, 15:637-646.

40. Niklasson L, Rasmussen P, Oskarsdottir S, Gillberg C: Autism, ADHD, mental retardation and behavior problems in 100 individuals with 22q11 deletion syndrome. Res Dev Disabil 2009, 30:763-773.

41. Geschwind DH: Autism: many genes, common pathways? Cell 2008, 135:391-395.

42. Gottesman, II, Gould TD: The endophenotype concept in psychiatry: etymology and strategic intentions. Am J Psychiatry 2003, 160:636-645.

43. Hatton DD, Sideris J, Skinner M, Mankowski J, Bailey DB Jr, Roberts J, Mirrett P: Autistic behavior in children with fragile $\mathrm{X}$ syndrome: prevalence, stability, and the impact of FMRP. Am J Med Genet A 2006, 140A:1804-1813.

44. Hunt A, Shepherd C: A prevalence study of autism in tuberous sclerosis. J Autism Dev Disord 1993, 23:323-339.

45. Abrahams BS, Geschwind DH: Connecting genes to brain in the autism spectrum disorders. Arch Neurol 2010, 67:395-399.

46. Wang K, Zhang H, Ma D, Bucan M, Glessner JT, Abrahams BS, Salyakina D, Imielinski M, Bradfield JP, Sleiman PM, Kim CE, Hou C, Frackelton E, Chiavacci R, Takahashi N, Sakurai T, Rappaport E, Lajonchere CM, Munson J, Estes A, Korvatska O, Piven J, Sonnenblick LI, Alvarez Retuerto Al, Herman El, Dong H, Hutman T, Sigman M, Ozonoff S, Klin A, et al:: Common genetic variants on 5 p14.1 associate with autism spectrum disorders. Nature 2009, 459:528-533.

47. Weiss LA, Arking DE, Daly MJ, Chakravarti A: A genome-wide linkage and association scan reveals novel loci for autism. Nature 2009, 461:802-808.

48. Anney R, Klei L, Pinto D, Regan R, Conroy J, Magalhaes TR, Correia C, Abrahams BS, Sykes N, Pagnamenta AT, Almeida J, Bacchelli E, Bailey AJ, Baird G, Battaglia A, Berney T, Bolshakova N, Bölte S, Bolton PF, Bourgeron T, Brennan S, Brian J, Carson AR, Casallo G, Casey J, Chu SH, Cochrane L, Corsello C, Crawford EL, Crossett A, et al: A genome-wide scan for common alleles affecting risk for autism. Hum Mol Genet 2010, 19:4072-4082

49. Sebat J, Lakshmi B, Malhotra D, Troge J, Lese-Martin C, Walsh T, Yamrom B, Yoon S, Krasnitz A, Kendall J, Leotta A, Pai D, Zhang R, Lee YH, Hicks J, Spence SJ, Lee AT, Puura K, Lehtimäki T, Ledbetter D, Gregersen PK, Bregman J, Sutcliffe JS, Jobanputra V, Chung W, Warburton D, King MC, Skuse D, Geschwind DH, Gilliam TC, et al: Strong association of de novo copy number mutations with autism. Science 2007, 316:445-449.

50. Szatmari P, Paterson AD, Zwaigenbaum L, Roberts W, Brian J, Liu XQ, Vincent JB, Skaug JL, Thompson AP, Senman L, Feuk L, Qian C, Bryson SE, Jones MB, Marshall CR, Scherer SW, Vieland VJ, Bartlett C, Mangin LV, Goedken R, Segre A, Pericak-Vance MA, Cuccaro ML, Gilbert JR, Wright HH, Abramson RK, Betancur C, Bourgeron T, Gillberg C, Leboyer M, et al:: Mapping autism risk loci using genetic linkage and chromosomal rearrangements. Nat Genet 2007, 39:319-328

51. Marshall CR, Noor A, Vincent JB, Lionel AC, Feuk L, Skaug J, Shago M, Moessner R, Pinto D, Ren Y, Thiruvahindrapduram B, Fiebig A, Schreiber S, Friedman J, Ketelaars CE, Vos YJ, Ficicioglu C, Kirkpatrick S, Nicolson R, Sloman L, Summers A, Gibbons CA, Teebi A, Chitayat D, Weksberg R, Thompson A, Vardy C, Crosbie V, Luscombe S, Baatjes R, et al: Structural variation of chromosomes in autism spectrum disorder. Am J Hum Genet 2008, 82:477-488.

52. Pinto D, Pagnamenta AT, Klei L, Anney R, Merico D, Regan R, Conroy J, Magalhaes TR, Correia C, Abrahams BS, Almeida J, Bacchelli E, Bader GD, Bailey AJ, Baird G, Battaglia A, Berney T, Bolshakova N, Bölte S, Bolton PF, Bourgeron T, Brennan S, Brian J, Bryson SE, Carson AR, Casallo G, Casey J, Chung BH, Cochrane L, Corsello C, et al.: Functional impact of global rare copy number variation in autism spectrum disorders. Nature 2010, 466:368-372.

53. Risch N, Merikangas $\mathrm{K}$ : The future of genetic studies of complex human diseases. Science 1996, 273:1516-1517.

54. Voineagu I: Gene expression studies in autism: moving from the genome to the transcriptome and beyond. Neurobiol Dis 2012, 45:69-75.

55. Bodmer W, Bonilla C: Common and rare variants in multifactoria susceptibility to common diseases. Nat Genet 2008, 40:695-701.

56. Ripke S, Sanders AR, Kendler KS, Levinson DF, Sklar P, Holmans PA, Lin DY, Duan J, Ophoff RA, Andreassen OA, Scolnick E, Cichon S, St Clair D, Corvin A, Gurling H, Werge T, Rujescu D, Blackwood DH, Pato CN, Malhotra AK, Purcell S, Dudbridge F, Neale BM, Rossin L, Visscher PM, Posthuma D, Ruderfer DM, Fanous A, Stefansson H, Steinberg S, et al:: Genome-wide association study identifies five new schizophrenia loci. Nat Genet 2011, 43:969-976.

57. Harold D, Abraham R, Hollingworth P, Sims R, Gerrish A, Hamshere ML, Pahwa JS, Moskvina V, Dowzell K, Williams A, Jones N, Thomas C, Stretton A, Morgan 
AR, Lovestone S, Powell J, Proitsi P, Lupton MK, Brayne C, Rubinsztein DC, Gill M, Lawlor B, Lynch A, Morgan K, Brown KS, Passmore PA, Craig D, McGuinness B, Todd S, Holmes C, et al:: Genome-wide association study identifies variants at CLU and PICALM associated with Alzheimer's disease. Nat Genet 2009, 41:1088-1093.

58. Golzio C, Willer J, Talkowski ME, Oh EC, Taniguchi Y, Jacquemont S, Reymond A, Sun M, Sawa A, Gusella JF, Kamiya A, Beckmann JS, Katsanis N: KCTD13 is a major driver of mirrored neuroanatomical phenotypes of the $16 \mathrm{p} 11.2$ copy number variant. Nature 2012,485:363-367.

59. Luo R, Sanders SJ, Tian Y, Voineagu I, Huang N, Chu SH, Klei L, Cai C, Ou J, Lowe JK, Hurles ME, Devlin B, State MW, Geschwind DH: Genome-wide transcriptome profiling reveals the functional impact of rare de novo and recurrent CNVs in autism spectrum disorders. Am J Hum Genet 2012, 91:38-55

60. Lauritsen MB, Pedersen CB, Mortensen PB: Effects of familial risk factors and place of birth on the risk of autism: a nationwide register-based study. J Child Psychol Psychiatry 2005, 46:963-971.

61. Reichenberg A, Gross R, Weiser M, Bresnahan M, Silverman J, Harlap S, Rabinowitz J, Shulman C, Malaspina D, Lubin G, Knobler HY, Davidson M, Susser E: Advancing paternal age and autism. Arch Gen Psychiatry 2006 63:1026-1032

62. Gabis $L$, Raz R, Kesner-Baruch Y: Paternal age in autism spectrum disorders and ADHD. Pediatr Neurol 2010, 43:300-302.

63. Lundström S, Haworth CM, Carlström E, Gillberg C, Mill J, Råstam M, Hultman CM, Ronald A, Anckarsäter H, Plomin R, Lichtenstein P, Reichenberg A: Trajectories leading to autism spectrum disorders are affected by paternal age: findings from two nationally representative twin studies. J Child Psychol Psychiatry 2010, 51:850-856.

64. Wexler EM, Rosen E, Lu D, Osborn GE, Martin E, Raybould H, Geschwind DH: Genome-wide analysis of a Wnt1-regulated transcriptional network implicates neurodegenerative pathways. Sci Signal 2011, 4:ra65.

65. Freimer N, Sabatti C: The use of pedigree, sib-pair and association studies of common diseases for genetic mapping and epidemiology. Nat Genet 2004, 36:1045-1051.

66. Gilman SR, lossifov I, Levy D, Ronemus M, Wigler M, Vitkup D: Rare de novo variants associated with autism implicate a large functional network of genes involved in formation and function of synapses. Neuron 2011, 70:898-907

67. Khwaja OS, Sahin M: Translational research: Rett syndrome and tuberous sclerosis complex. Curr Opin Pediatr 2011, 23:633-639.

68. Strauss KA, Puffenberger EG, Huentelman MJ, Gottlieb S, Dobrin SE, Parod JM, Stephan DA, Morton DH: Recessive symptomatic focal epilepsy and mutant contactin-associated protein-like 2. N Engl J Med 2006, 354:1370-1377.

69. Tierney E, Nwokoro NA, Porter FD, Freund LS, Ghuman JK, Kelley RI: Behavior phenotype in the RSH/Smith-Lemli-Opitz syndrome. Am J Med Genet 2001, 98:191-200.

70. Splawski I, Timothy KW, Sharpe LM, Decher N, Kumar P, Bloise R, Napolitano C, Schwartz PJ, Joseph RM, Condouris K, Tager-Flusberg H, Priori SG, Sanguinetti MC, Keating MT: $\mathrm{Ca}(\mathrm{V}) 1.2$ calcium channel dysfunction causes a multisystem disorder including arrhythmia and autism. Cell 2004 119:19-31.

71. Butler MG, Dasouki MJ, Zhou XP, Talebizadeh Z, Brown M, Takahashi TN, Miles $J$, Wang $\mathrm{CH}$, Stratton R, Pilarski R, Eng C: Subset of individuals with autism spectrum disorders and extreme macrocephaly associated with germline PTEN tumour suppressor gene mutations. J Med Genet 2005, 42:318-321.

72. Harris SW, HessI D, Goodlin-Jones B, Ferranti J, Bacalman S, Barbato I, Tassone F, Hagerman PJ, Herman H, Hagerman RJ: Autism profiles of males with fragile X syndrome. Am J Ment Retard 2008, 113:427-438.

73. Kertesz A: The overlapping syndromes of the pick complex. Curr Alzheimer Res 2011, 8:224-228.

74. Vorstman JA, Staal WG, van Daalen E, van Engeland H, Hochstenbach PF, Franke L: Identification of novel autism candidate regions through analysis of reported cytogenetic abnormalities associated with autism. Mol Psychiatry 2006, 11:1, 18-28.

75. Bucan M, Abrahams BS, Wang K, Glessner JT, Herman El, Sonnenblick LI, Alvarez Retuerto Al, Imielinski M, Hadley D, Bradfield JP, Kim C, Gidaya NB, Lindquist I, Hutman T, Sigman M, Kustanovich V, Lajonchere CM, Singleton A, Kim J, Wassink TH, McMahon WM, Owley T, Sweeney JA, Coon H, Nurnberger JI, Li M, Cantor RM, Minshew NJ, Sutcliffe JS, Cook EH, et al:: Genome-wide analyses of exonic copy number variants in a family-based study point to novel autism susceptibility genes. PLoS Genet 2009, 5:e1000536.
76. Kumar RA, KaraMohamed S, Sudi J, Conrad DF, Brune C, Badner JA, Gilliam TC, Nowak NJ, Cook EH, Dobyns WB, Christian SL: Recurrent 16p11.2 microdeletions in autism. Hum Mol Genet 2008, 17:628-638.

77. Ben-David E, Shifman S: Networks of neuronal genes affected by common and rare variants in autism spectrum disorders. PLoS Genet 2012, 8:e1002556.

78. Berger AH, Knudson AG, Pandolfi PP: A continuum model for tumour suppression. Nature 2011, 476:163-169.

79. O'Roak BJ, Deriziotis P, Lee C, Vives L, Schwartz JJ, Girirajan S, Karakoc E, Mackenzie AP, Ng SB, Baker C, Rieder MJ, Nickerson DA, Bernier R, Fisher SE, Shendure J, Eichler EE: Exome sequencing in sporadic autism spectrum disorders identifies severe de novo mutations. Nat Genet 2011, 43:585-589.

80. Sakai Y, Shaw CA, Dawson BC, Dugas DV, Al-Mohtaseb Z, Hill DE, Zoghbi HY: Protein interactome reveals converging molecular pathways among autism disorders. Sci Trans/ Med 2011, 3:86ra49.

81. The Allen Brain Atlas [http://www.brain-map.org/]

82. Gene Paint [http://www.genepaint.org/]

83. The Cerebellar Development Transcriptome Database [http://www.cdtdb.neuroinf.jp/CDT/Top.jsp]

84. MedicalGenomics: Ref-Seq Atlas [http://medicalgenomics.org/rna_seq_atlas]

85. Prasad TS, Kandasamy K, Pandey A: Human Protein Reference Database and Human Proteinpedia as discovery tools for systems biology. Methods Mol Biol 2009, 577:67-79.

86. The Human Protein Reference Database [http://www.hprd.org/]

87. NIA mouse protein-protein interaction database [http://gsun.grc.nia.nih.gov/mppi/]

88. Genes to Cognition database [http://www.g2conline.org]

89. Zweier C, de Jong EK, Zweier M, Orrico A, Ousager LB, Collins AL, Bijlsma EK, Oortveld MA, Ekici AB, Reis A, Schenck A, Rauch A: CNTNAP2 and NRXN1 are mutated in autosomal-recessive Pitt-Hopkins-like mental retardation and determine the level of a common synaptic protein in Drosophila. Am J Hum Genet 2009, 85:655-666.

90. Ishizuka A, Siomi MC, Siomi H: A Drosophila fragile X protein interacts with components of RNAi and ribosomal proteins. Genes Dev 2002 16:2497-2508

91. Zhang YQ, Bailey AM, Matthies HJ, Renden RB, Smith MA, Speese SD, Rubin GM, Broadie K: Drosophila fragile X-related gene regulates the MAP1B homolog Futsch to control synaptic structure and function. Cell 2001, 107:591-603

92. Silverman JL, Yang M, Lord C, Crawley JN: Behavioural phenotyping assays for mouse models of autism. Nat Rev Neurosci 2010, 11:490-502.

93. Peñagarikano O, Abrahams BS, Herman El, Winden KD, Gdalyahu A, Dong H, Sonnenblick LI, Gruver R, Almajano J, Bragin A, Golshani P, Trachtenberg JT, Peles E, Geschwind DH: Absence of CNTNAP2 leads to epilepsy, neuronal migration abnormalities, and core autism-related deficits. Cell 2011, 147:235-246.

94. Jamain S, Radyushkin K, Hammerschmidt K, Granon S, Boretius S, Varoqueaux F, Ramanantsoa N, Gallego J, Ronnenberg A, Winter D, Frahm J, Fischer J, Bourgeron T, Ehrenreich $\mathrm{H}$, Brose $\mathrm{N}$ : Reduced social interaction and ultrasonic communication in a mouse model of monogenic heritable autism. Proc Natl Acad Sci USA 2008, 105:1710-1715.

95. Cheh MA, Millonig JH, Roselli LM, Ming X, Jacobsen E, Kamdar S, Wagner GC: En2 knockout mice display neurobehavioral and neurochemical alterations relevant to autism spectrum disorder. Brain Res 2006 1116:166-176.

96. Moy SS, Nadler JJ, Young NB, Nonneman RJ, Grossman AW, Murphy DL, D'Ercole AJ, Crawley JN, Magnuson TR, Lauder JM: Social approach in genetically engineered mouse lines relevant to autism. Genes Brain Behav 2009, 8:129-142.

97. Nakatani J, Tamada K, Hatanaka F, Ise S, Ohta H, Inoue K, Tomonaga S, Watanabe Y, Chung YJ, Banerjee R, Iwamoto K, Kato T, Okazawa M, Yamauchi K, Tanda K, Takao K, Miyakawa T, Bradley A, Takumi T: Abnormal behavior in a chromosome-engineered mouse model for human 15q11-13 duplication seen in autism. Cell 2009, 137:1235-1246.

98. DeLorey TM, Sahbaie P, Hashemi E, Homanics GE, Clark JD: Gabrb3 gene deficient mice exhibit impaired social and exploratory behaviors, deficits in non-selective attention and hypoplasia of cerebellar vermal lobules: a potential model of autism spectrum disorder. Behav Brain Res 2008 , 187:207-220.

99. Crawley JN, Chen T, Puri A, Washburn R, Sullivan TL, Hill JM, Young NB, Nadler 
$J$ J, Moy SS, Young LJ, Caldwell HK, Young WS: Social approach behaviors in oxytocin knockout mice: comparison of two independent lines tested in different laboratory environments. Neuropeptides 2007, 41:145-163.

100. Ferguson JN, Young $\amalg$, Hearn EF, Matzuk MM, Insel TR, Winslow JT: Social amnesia in mice lacking the oxytocin gene. Nat Genet 2000, 25:284-288

101. Winslow JT, Hearn EF, Ferguson J, Young $\sqcup$, Matzuk MM, Insel TR: Infant vocalization, adult aggression, and fear behavior of an oxytocin null mutant mouse. Horm Behav 2000, 37:145-155.

102. Wersinger SR, Ginns El, O'Carroll AM, Lolait SJ, Young WS, 3rd: Vasopressin $\mathrm{V} 1 \mathrm{~b}$ receptor knockout reduces aggressive behavior in male mice. $\mathrm{Mol}$ Psychiatry 2002, 7:975-984.

103. Scattoni ML, McFarlane HG, Zhodzishsky V, Caldwell HK, Young WS, Ricceri L, Crawley JN: Reduced ultrasonic vocalizations in vasopressin $1 \mathrm{~b}$ knockout mice. Behav Brain Res 2008, 187:371-378.

104. Scearce-Levie K, Roberson ED, Gerstein H, Cholfin JA, Mandiyan VS, Shah NM, Rubenstein JL, Mucke L: Abnormal social behaviors in mice lacking Fgf17. Genes Brain Behav 2008, 7:344-354

105. Barnby G, Abbott A, Sykes N, Morris A, Weeks DE, Mott R, Lamb J, Bailey AJ Monaco AP: Candidate-gene screening and association analysis at the autism-susceptibility locus on chromosome 16p: evidence of association at GRIN2A and ABAT. Am J Hum Genet 2005, 76:950-966

106. Jamain S, Betancur C, Quach H, Philippe A, Fellous M, Giros B, Gillberg C, Leboyer M, Bourgeron T: Linkage and association of the glutamate receptor 6 gene with autism. Mol Psychiatry 2002, 7:302-310.

107. Jacquemont ML, Sanlaville D, Redon R, Raoul O, Cormier-Daire V, Lyonnet S, Amiel J, Le Merrer M, Heron D, de Blois MC, Prieur M, Vekemans M, Carter NP, Munnich A, Colleaux L, Philippe A: Array-based comparative genomic hybridisation identifies high frequency of cryptic chromosomal rearrangements in patients with syndromic autism spectrum disorders. J Med Genet 2006, 43:843-849.

108. Splawski I, Yoo DS, Stotz SC, Cherry A, Clapham DE, Keating MT: CACNA1H mutations in autism spectrum disorders. J Biol Chem 2006, 281:22085-22091.

109. Glessner JT, Wang K, Cai G, Korvatska O, Kim CE, Wood S, Zhang H, Estes A, Brune CW, Bradfield JP, Imielinski M, Frackelton EC, Reichert J, Crawford EL, Munson J, Sleiman PM, Chiavacci R, Annaiah K, Thomas K, Hou C, Glaberson W, Flory J, Otieno F, Garris M, Soorya L, Klei L, Piven J, Meyer KJ, Anagnostou E, Sakurai T, et al: Autism genome-wide copy number variation reveals ubiquitin and neuronal genes. Nature 2009, 459:569-573.

110. Morrow EM, Yoo SY, Flavell SW, Kim TK, Lin Y, Hill RS, Mukaddes NM, Balkhy S, Gascon G, Hashmi A, Al-Saad S, Ware J, Joseph RM, Greenblatt R, Gleason D, Ertelt JA, Apse KA, Bodell A, Partlow JN, Barry B, Yao H, Markianos K, Ferland RJ, Greenberg ME, Walsh CA: Identifying autism loci and genes by tracing recent shared ancestry. Science 2008, 321:218-223.

111. Flavell SW, Kim TK, Gray JM, Harmin DA, Hemberg M, Hong EJ, MarkenscoffPapadimitriou E, Bear DM, Greenberg ME: Genome-wide analysis of MEF2 transcriptional program reveals synaptic target genes and neuronal activity-dependent polyadenylation site selection. Neuron 2008, 60:1022-1038

112. Chahrour MH, Yu TW, Lim ET, Ataman B, Coulter ME, Hill RS, Stevens CR, Schubert CR, Greenberg ME, Gabriel SB, Walsh CA: Whole-exome sequencing and homozygosity analysis implicate depolarizationregulated neuronal genes in autism. PLoS Genet 2012, 8:e1002635.

113. De Rubeis S, Bagni C: Regulation of molecular pathways in the Fragile $X$ Syndrome: insights into Autism Spectrum Disorders. J Neurodev Disord 2011, 3:257-269

114. Bassell GJ, Warren ST: Fragile X syndrome: loss of local mRNA regulation alters synaptic development and function. Neuron 2008, 60:201-214.

115. Napoli I, Mercaldo V, Boyl PP, Eleuteri B, Zalfa F, De Rubeis S, Di Marino D, Mohr E, Massimi M, Falconi M, Witke W, Costa-Mattioli M, Sonenberg N, Achsel T, Bagni C: The fragile $X$ syndrome protein represses activity-dependent translation through CYFIP1, a new 4E-BP. Cell 2008, 134:1042-1054.

116. Campbell DB, Sutcliffe JS, Ebert PJ, Militerni R, Bravaccio C, Trillo S, Elia M, Schneider C, Melmed R, Sacco R, Persico AM, Levitt P: A genetic variant that disrupts MET transcription is associated with autism. Proc Natl Acad Sci USA 2006, 103:16834-16839.

117. Williams PG, Hersh JH: Brief report: the association of neurofibromatosis type 1 and autism. J Autism Dev Disord 1998, 28:567-571.

118. Kelleher RJ, 3rd, Bear MF: The autistic neuron: troubled translation? Cell 2008, 135:401-406

119. Waung MW, Huber KM: Protein translation in synaptic plasticity: mGluR-
LTD, Fragile X. Curr Opin Neurobiol 2009, 19:319-326

120. Zoghbi HY, Bear MF: Synaptic dysfunction in neurodevelopmental disorders associated with autism and intellectual disabilities. Cold Spring Harb Perspect Biol 2012, 4:a009886.

121. Hou L, Klann E: Activation of the phosphoinositide 3-kinase-Aktmammalian target of rapamycin signaling pathway is required for metabotropic glutamate receptor-dependent long-term depression. J Neurosci 2004, 24:6352-6361.

122. Sarbassov DD, Ali SM, Sabatini DM: Growing roles for the mTOR pathway. Curr Opin Cell Biol 2005, 17:596-603.

123. Scheiffele P, Beg AA: Neuroscience: Angelman syndrome connections. Nature 2010, 468:907-908.

124. Durand CM, Betancur C, Boeckers TM, Bockmann J, Chaste P, Fauchereau F, Nygren G, Rastam M, Gillberg IC, Anckarsäter H, Sponheim E, Goubran-Botros H, Delorme R, Chabane N, Mouren-Simeoni MC, de Mas P, Bieth E, Rogé B, Héron D, Burglen L, Gillberg C, Leboyer M, Bourgeron T: Mutations in the gene encoding the synaptic scaffolding protein SHANK3 are associated with autism spectrum disorders. Nat Genet 2007, 39:25-27.

125. Berkel S, Marshall CR, Weiss B, Howe J, Roeth R, Moog U, Endris V, Roberts W, Szatmari P, Pinto D, Bonin M, Riess A, Engels H, Sprengel R, Scherer SW, Rappold GA: Mutations in the SHANK2 synaptic scaffolding gene in autism spectrum disorder and mental retardation. Nat Genet 2010, 42:489-491.

126. Scott-Van Zeeland AA, Abrahams BS, Alvarez-Retuerto Al, Sonnenblick LI, Rudie JD, Ghahremani D, Mumford JA, Poldrack RA, Dapretto M, Geschwind $\mathrm{DH}$, Bookheimer SY: Altered functional connectivity in frontal lobe circuits is associated with variation in the autism risk gene CNTNAP2. Sci Trans/ Med 2010, 2:56ra80

127. Poliak S, Gollan L, Martinez R, Custer A, Einheber S, Salzer JL, Trimmer JS, Shrager P, Peles E: Caspr2, a new member of the neurexin superfamily, is localized at the juxtaparanodes of myelinated axons and associates with K+ channels. Neuron 1999, 24:1037-1047.

128. Roohi J, Montagna C, Tegay DH, Palmer LE, DeVincent C, Pomeroy JC, Christian SL, Nowak N, Hatchwell E: Disruption of contactin 4 in three subjects with autism spectrum disorder. J Med Genet 2009, 46:176-182.

129. Fernandez T, Morgan T, Davis N, Klin A, Morris A, Farhi A, Lifton RP, State MW: Disruption of Contactin 4 (CNTN4) results in developmental delay and other features of 3p deletion syndrome. Am J Hum Genet 2008, 82:1385.

130. Cottrell CE, Bir N, Varga E, Alvarez CE, Bouyain S, Zernzach R, Thrush DL, Evans J, Trimarchi M, Butter EM, Cunningham D, Gastier-Foster JM, McBride KL, Herman GE: Contactin 4 as an autism susceptibility locus. Autism Res 2011, 4:189-199

131. Itsara A, Wu H, Smith JD, Nickerson DA, Romieu I, London SJ, Eichler EE: De novo rates and selection of large copy number variation. Genome Res 2010 20:1469-1481.

132. Hines RM, Wu L, Hines DJ, Steenland H, Mansour S, Dahlhaus R, Singaraja RR, Cao X, Sammler E, Hormuzdi SG, Zhuo M, El-Husseini A: Synaptic imbalance, stereotypies, and impaired social interactions in mice with altered neuroligin 2 expression. J Neurosci 2008, 28:6055-6067.

133. Kim HG, Kishikawa S, Higgins AW, Seong IS, Donovan DJ, Shen Y, Lally E, Weiss LA, Najm J, Kutsche K, Descartes M, Holt L, Braddock S, Troxell R, Kaplan L, Volkmar F, Klin A, Tsatsanis K, Harris DJ, Noens I, Pauls DL, Daly MJ, MacDonald ME, Morton CC, Quade BJ, Gusella JF: Disruption of neurexin 1 associated with autism spectrum disorder. Am J Hum Genet 2008, 82:199-207.

134. Jamain S, Quach H, Betancur C, Råstam M, Colineaux C, Gillberg IC, Soderstrom H, Giros B, Leboyer M, Gillberg C, Bourgeron T: Mutations of the X-linked genes encoding neuroligins NLGN3 and NLGN4 are associated with autism. Nat Genet 2003, 34:27-29.

135. Laumonnier F, Bonnet-Brilhault F, Gomot M, Blanc R, David A, Moizard MP, Raynaud M, Ronce N, Lemonnier E, Calvas P, Laudier B, Chelly J, Fryns JP, Ropers HH, Hamel BC, Andres C, Barthélémy C, Moraine C, Briault S: X-linked mental retardation and autism are associated with a mutation in the NLGN4 gene, a member of the neuroligin family. Am J Hum Genet 2004, 74:552-557.

136. Tabuchi K, Blundell J, Etherton MR, Hammer RE, Liu X, Powell CM, Sudhof TC: A neuroligin-3 mutation implicated in autism increases inhibitory synaptic transmission in mice. Science 2007, 318:71-76.

137. Etherton MR, Blaiss CA, Powell CM, Sudhof TC: Mouse neurexin-1alpha deletion causes correlated electrophysiological and behavioral changes consistent with cognitive impairments. Proc Natl Acad Sci USA 2009, 106:17998-18003.

138. Peca J, Feliciano C, Ting JT, Wang W, Wells MF, Venkatraman TN, Lascola CD, Fu 
Z, Feng G: Shank3 mutant mice display autistic-like behaviours and striatal dysfunction. Nature 2011, 472:437-442.

139. Olmos-Serrano JL, Paluszkiewicz SM, Martin BS, Kaufmann WE, Corbin JG, Huntsman MM: Defective GABAergic neurotransmission and pharmacological rescue of neuronal hyperexcitability in the amygdala in a mouse model of fragile X syndrome. J Neurosci 2010, 30:9929-9938.

140. Gibson JR, Bartley AF, Hays SA, Huber KM: Imbalance of neocortical excitation and inhibition and altered UP states reflect network hyperexcitability in the mouse model of fragile X syndrome. J Neurophysiol 2008, 100:2615-2626.

141. Centonze D, Rossi S, Mercaldo V, Napoli I, Ciotti MT, De Chiara V, Musella A Prosperetti C, Calabresi P, Bernardi G, Bagni C: Abnormal striatal GABA transmission in the mouse model for the fragile $\mathrm{X}$ syndrome. Biol Psychiatry 2008, 63:963-973.

142. Voineagu I, Wang X, Johnston P, Lowe JK, Tian Y, Horvath S, Mill J, Cantor RM, Blencowe BJ, Geschwind DH: Transcriptomic analysis of autistic brain reveals convergent molecular pathology. Nature 2011, 474:380-384

143. Oldham MC, Konopka G, Iwamoto K, Langfelder P, Kato T, Horvath S, Geschwind DH: Functional organization of the transcriptome in human brain. Nat Neurosci 2008, 11:1271-1282.

144. Courchesne E, Carper R, Akshoomoff N: Evidence of brain overgrowth in the first year of life in autism. JAMA 2003, 290:337-344.

145. Redcay E, Courchesne $E:$ When is the brain enlarged in autism? A metaanalysis of all brain size reports. Biol Psychiatry 2005, 58:1-9.

146. Sacco R, Militerni R, Frolli A, Bravaccio C, Gritti A, Elia M, Curatolo P, Manzi B, Trillo S, Lenti C, Saccani M, Schneider C, Melmed R, Reichelt KL, Pascucci T, Puglisi-Allegra S, Persico AM: Clinical, morphological, and biochemical correlates of head circumference in autism. Biol Psychiatry 2007, 62:1038-1047.

147. Barnea-Goraly N, Kwon H, Menon V, Eliez S, Lotspeich L, Reiss AL: White matter structure in autism: preliminary evidence from diffusion tensor imaging. Biol Psychiatry 2004, 55:323-326.

148. Alexander AL, Lee JE, Lazar M, Boudos R, DuBray MB, Oakes TR, Miller JN, Lu J Jeong EK, MCMahon WM, Bigler ED, Lainhart JE: Diffusion tensor imaging of the corpus callosum in autism. Neuroimage 2007, 34:61-73.

149. Geschwind DH, Levitt P: Autism spectrum disorders: developmental disconnection syndromes. Curr Opin Neurobiol 2007, 17:103-111.

150. Courchesne E, Pierce K: Why the frontal cortex in autism might be talking only to itself: local over-connectivity but long-distance disconnection. Curr Opin Neurobiol 2005, 15:225-230.

151. Casanova MF, van Kooten IA, Switala AE, van Engeland H, Heinsen $H$ Steinbusch HW, Hof PR, Trippe J, Stone J, Schmitz C: Minicolumnar abnormalities in autism. Acta Neuropathol 2006, 112:287-303.

152. Kaiser MD, Hudac CM, Shultz S, Lee SM, Cheung C, Berken AM, Deen B, Pitskel NB, Sugrue DR, Voos AC, Saulnier CA, Ventola P, Wolf JM, Klin A, Vander Wyk BC, Pelphrey KA: Neural signatures of autism. Proc Natl Acad Sci USA 2010, 107:21223-21228.

153. Pierce K: Early functional brain development in autism and the promise of sleep fMRI. Brain Res 2011, 1380:162-174.

154. Penagarikano O, Geschwind DH: What does CNTNAP2 reveal about autism spectrum disorder? Trends Mol Med 2012, 18:156-163.

155. Kohane IS, Masys DR, Altman RB: The incidentalome: a threat to genomic medicine. JAMA 2006, 296:212-215.

156. Schaaf CP, Sabo A, Sakai Y, Crosby J, Muzny D, Hawes A, Lewis L, Akbar H, Varghese R, Boerwinkle E, Gibbs RA, Zoghbi HY: Oligogenic heterozygosity in individuals with high-functioning autism spectrum disorders. Hum Mol Genet 2011, 20:3366-3375.

157. Allen Brain Atlas: Mouse Brain [http://mouse.brain-map.org]

158. Kerin T, Ramanathan A, Rivas K, Grepo N, Coetzee GA, Campbell DB: A noncoding RNA antisense to moesin at 5p14.1 in autism. Sci Trans/Med 2012, 4:128ra140.

doi:10.1186/gb-2012-13-7-247

Cite this article as: Berg JM, Geschwind DH: Autism genetics: searching for specificity and convergence. Genome Biology 2012, 13:247. 